\title{
Early pregnancy modulates survival and apoptosis pathways in the corpus luteum in sheep
}

\author{
JeHoon Lee, Sakhila K Banu, John A McCracken ${ }^{1}$ and Joe A Arosh \\ Reproductive Endocrinology and Cell Signaling Laboratory, Department of Veterinary Integrative Biosciences, College \\ of Veterinary Medicine and Biomedical Sciences, Mail Stop: TAMU 4458, Texas A\&M University, College Station, \\ Texas 77843, USA and ${ }^{1}$ Department of Animal Science, University of Connecticut, Storrs, Connecticut 06269, USA
}

Correspondence should be addressed to J A Arosh; Email: jarosh@cvm.tamu.edu

\begin{abstract}
The corpus luteum (CL) is a transient endocrine gland. Functional and structural demise of the CL allows a new estrous cycle. On the other hand, survival of $C L$ and its secretion of progesterone are required for the establishment of pregnancy. Survival or apoptosis of the luteal cells is precisely controlled by interactions between survival and apoptosis pathways. Regulation of these cell signaling components during natural luteolysis and establishment of pregnancy is largely unknown in ruminants. The objective of the present study was to determine the regulation of survival and apoptosis signaling protein machinery in the CL on days 12, 14, and 16 of the estrous cycle and pregnancy in sheep. Results indicate that: i) expressions of p-ERK1/2, p-AKT, $\beta$-catenin, NFKB -p65, -p50, -p52, p-Src, p- $\beta$-arrestin, p-GSK3 $\beta$, X-linked inhibitor of apoptosis protein (XIAP), and p-CREB proteins are suppressed during natural luteolysis; in contrast, their expressions are sustained or increased during establishment of pregnancy; ii) expressions of cleaved caspase-3, apoptosis inducing factor (AIF), c-Fos, c-Jun, and EGR-1 proteins are increased during natural luteolysis; in contrast, their expressions are decreased during establishment of pregnancy; and iii) expressions of Bcl-2, Bcl-XL, Bad, and Bax proteins are not modulated during natural luteolysis while expressions of Bcl2 and Bcl-XL proteins are increased during establishment of pregnancy in sheep. These proteomic changes are evident in both large and small luteal cells. These results together indicate that regression of the $C L$ during natural luteolysis or survival of the $C L$ during establishment of pregnancy is precisely controlled by distinct programmed suppression or activation of intraluteal cell survival and apoptosis pathways in sheep/ruminants.

Reproduction (2016) 151 187-202
\end{abstract}

\section{Introduction}

In ruminants, prostaglandin $\mathrm{F}_{2 \alpha}\left(\mathrm{PGF}_{2 \alpha}\right)$ is the luteolytic hormone (McCracken et al. 1999). During the process of luteolysis, $\mathrm{PGF}_{2 \alpha}$ is synthesized and released from the endometrial luminal epithelial cells in a pulsatile pattern which causes luteolysis. In sheep, continuous exposure of endometrium to progesterone $\left(\mathrm{P}_{4}\right)$ for 8-10 days down-regulates expression of nuclear $\mathrm{P}_{4}$ receptor in luminal epithelial cells between days 11 and 13, thereby allowing a rapid increase in expression of nuclear $E_{2}$ receptor $\alpha$ (ESR-1) after day 13 , followed by an increase in expression of membrane oxytocin receptor (OXTR) after day 14 of the estrous cycle (McCracken et al. 1999, Spencer et al. 2004). Pulsatile releases of oxytocin from the posterior pituitary and corpus luteum (CL) after days 13-14 of the estrous cycle act via OXTR to induce release of luteolytic pulses of $\mathrm{PGF}_{2 \alpha}$ from luminal epithelial cells between days 14 and 16 of the estrous cycle (McCracken et al. 1999). Endometrial $\mathrm{PGF}_{2 \alpha}$ is transported into each adjacent uterine vein which joins the adjacent ovarian vein to form the utero-ovarian vein.
Luteolytic $\mathrm{PGF}_{2 \alpha}$ pulses are transported from the uteroovarian vein into the ovarian artery locally through a complex vascular structure called the utero-ovarian plexus (UOP) (Lee et al. 2010). A minimum of five 1-h long pulses of $\mathrm{PGF}_{2 \alpha}$ over a period of $48 \mathrm{~h}$ is required to cause complete luteolysis consistently in sheep (McCracken et al. 2012).

At the time of establishment of pregnancy, interferon tau secreted by the trophoblast of the conceptus inhibits endometrial pulsatile release of $\mathrm{PGF}_{2 \alpha}$ and prevents luteolysis (Spencer et al. 2004). Experiments involving anastomosis of uterine vein or ovarian artery from pregnant to nonpregnant uterine horn indicate that both luteolytic and luteoprotective mediators need to be transported from the utero-ovarian vein to the ovarian artery via the UOP in sheep and cattle (Mapletoft \& Ginther 1975, Mapletoft et al. 1975, 1976a,b, Ginther 1981). Embryo/conceptus transfer and hysterectomy experiments indicate that the luteolytic and luteoprotective mechanisms are locally mediated between the uterus and the CL of the ipsilateral ovary and do not act systemically in sheep (Moor \& Rowson 1966a, Moor 
et al. 1969, 1970). Early studies indicate that during the establishment of pregnancy in sheep, a factor(s) from the conceptus or gravid uterus reaches the ovary locally through the UOP and protects the $\mathrm{CL}$ from luteolysis (Moor \& Rowson 1966a,b, Moor et al. 1969, Mapletoft \& Ginther 1975, Mapletoft et al. 1975, 1976a, Silvia \& Niswender 1986).

In ruminants, the $\mathrm{CL}$ of early pregnancy is more resistant to the luteolytic action of $\mathrm{PGF}_{2 \alpha}$ (Inskeep et al. 1975, Pratt et al. 1977, Nancarrow et al. 1982, Silvia \& Niswender 1984, 1986) on days 12-16, and the resistance is even greater when multiple embryos are present (Nancarrow et al. 1982). Injection of $\mathrm{PGF}_{2 \alpha}$ into an ovarian artery or follicles of early pregnant sheep causes luteolysis in $28 \%$ or $17 \%$ of animals compared with $78 \%$ or $83 \%$ in nonpregnant sheep respectively (Inskeep et al. 1975, Pratt et al. 1977). Exogenous estradiol at doses causing premature luteolysis in cyclic sheep is less effective in pregnant sheep (Kittok \& Britt 1977). Infusions of IFNT directly into the uterine vein maintained a functional $\mathrm{CL}$ in $80 \%$ of sheep for up to 32 days through yet unidentified mechanisms (Oliveira et al. 2008, Bott et al. 2010). Intraovarian administration of $\mathrm{PGE}_{2}$ dose dependently counteracts the luteolytic actions of $\mathrm{PGF}_{2 \alpha}$ (Henderson et al. 1977). Intrauterine or intraovarian infusions of $\mathrm{PGE}_{2}$ in nonpregnant ewes extend the inter-estrus interval and reduce luteal sensitivity to both endogenously secreted and exogenously administered PGF $_{2 \alpha}$ (Henderson et al. 1977, Pratt et al. 1977, 1979, Magness et al. 1981, Reynolds et al. 1981, Weems et al. 2006). Our resent study (Lee et al. 2012) shows that during establishment of pregnancy, a large proportion of $\mathrm{PGE}_{2}$ is transported from the uterus to the ovary through the UOP. Luteal PG biosynthesis is selectively directed towards $\mathrm{PGF}_{2 \alpha}$ at the time of luteolysis; by contrast, towards $\mathrm{PGE}_{2}$ during establishment of pregnancy.

Our current understanding is that regression of $\mathrm{CL}$ occurs in two phases: i) functional luteolysis and ii) structural luteolysis. Functional luteolysis is defined as decrease in $\mathrm{P}_{4}$ secretion whereas structural luteolysis is defined as loss of luteal cells and volume (McCracken et al. 1999). It is well accepted that functional luteolysis precedes structural luteolysis. A recent study indicates that inhibition of luteal PG production by indomethacin at mid cycle decreases $\mathrm{P}_{4}$ levels and induces functional luteolysis, however; it does not decrease size and weight of the $\mathrm{CL}$ or induce structural luteolysis in sheep (Niswender et al. 2007). It suggests that existence of distinct or separate mechanism that governs the functional vs structural luteolysis in sheep. $\mathrm{P}_{4}$ secreted by the $C L$ is required for establishment of pregnancy. Secretion of $\mathrm{P}_{4}$ depends on the survival and healthy status of luteal cells which is precisely controlled by interactions between cell survival and apoptosis pathways. ERK1/2, AKT, $\beta$-Catenin and NFKB pathways are the important intracellular pathways determine survival of cells (Datta et al. 1997, Bonni et al. 1999, Kumar et al. 2004, Grigoryan et al. 2008). By contrast, interactions between pro-apoptotic and anti-apoptotic signaling pathways and activation of caspases-3 dependent or independent intrinsic apoptosis pathways determine the death of cells (Adams \& Cory 1998, Jiang \& Wang 2004). Previous studies have shown that administration $\mathrm{PGF}_{2 \alpha}$ regulates genes or protein associated with cell survival and apoptosis in cows (Davis \& Rueda 2002, Hou et al. 2008, Arvisais et al. 2010, Atli et al. 2012), sheep (Romero et al. 2013), pigs (Diaz et al. 2013), rodents (Carambula et al. 2002, Slot et al. 2006), and primates (Peluffo et al. 2005, Yadav et al. 2005) during induced luteolysis in vivo and in vitro models. Although there is a large body of information available on induced luteolysis in various species, temporal regulations of cell survival and apoptosis signaling protein machinery in the $\mathrm{CL}$ during natural luteolysis and establishment of pregnancy in ruminants are largely unknown. The objective of the present study was to determine the effects of early pregnancy on regulation of survival and apoptosis signaling protein machinery in the $C L$ on days 12,14 , and 16 in sheep, using as a ruminant model.

\section{Materials and methods}

\section{Materials}

Prestained protein markers, Bio-Rad assay reagents and standards (Bio-RAD Laboratories); protran BA83 Nitrocellulose membrane (Whatman, Inc., Sanford, ME, USA); pierce ECL (Pierce, Rockford, IL, USA); protease inhibitor (Roche Applied Biosciences); Vectastain Elite ABC kit (Vector Laboratories, Inc., Burlingame, CA, USA); Progesterone RIA kits (Diagnostic Systems Laboratories, Webster, TX, USA); Blue X-ray film (Phoenix Research Products, Hayward, CA, USA) were purchased. Details of antibodies used in this study are given in Table 1. The other chemicals used were molecular biological grade from Fisher (Pittsburgh, PA, USA) or Sigma-Aldrich.

\section{Animal husbandry}

All experiments were in accordance with the Guide for Care and Use of Agricultural Animals and approved by Texas A\&M University's Laboratory Animal Care and Use Committee. Mature crossbred Suffolk ewes (Ovis aries) were observed daily for estrus in the presence of vasectomized rams. Ewes that had exhibited at least two estrous cycles of normal duration (17-18 days) were used in this study. At estrus (day 0), the ewes were bred to either an intact or a vasectomized ram. The ewes ( $n=4$ per day) were necropsied on days 12,14 , or 16 of the estrous cycle or pregnancy as described previously (Banu et al. 2008a, Simmons et al. 2010). The uterus was flushed with $20 \mathrm{ml}$ physiological saline and pregnancy was confirmed on each day by the presence of a normal conceptus in the uterine lumen flushing as described previously (Simmons et al. 2010). The ovaries were collected and the $\mathrm{CL}$ isolated. Longitudinal 


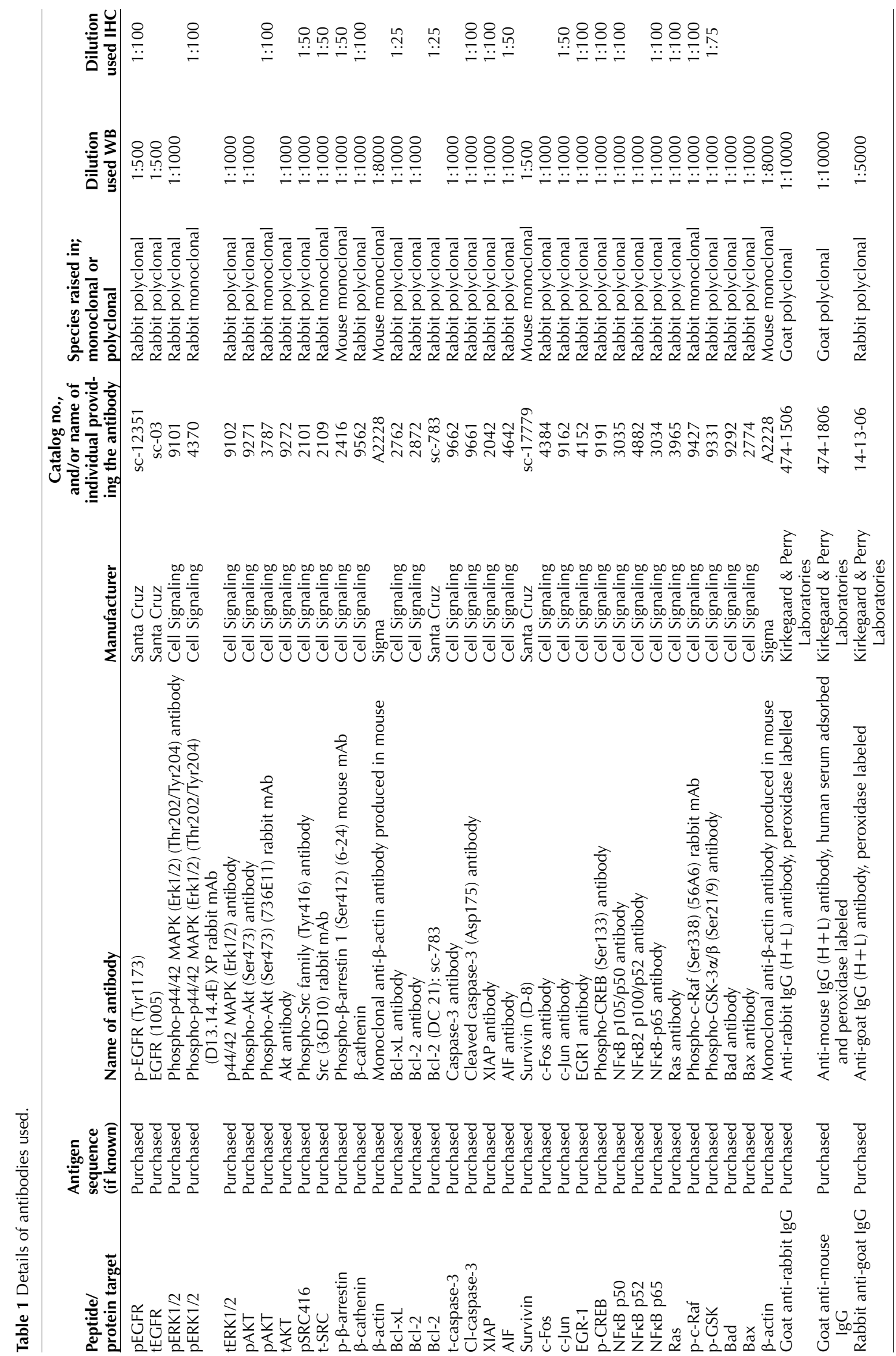


cross sections were cut in the middle of each $\mathrm{CL}$ and fixed in fresh $4 \%$ buffered paraformaldehyde, and processed for immunohistochemistry using standard procedures. The remaining $\mathrm{CL}$ tissue was cut into small pieces, snap-frozen in liquid nitrogen, and stored at $-80^{\circ} \mathrm{C}$ for further analysis.

\section{Protein extraction}

Total protein was isolated from $\mathrm{CL}$ tissues as we described previously (Arosh et al. 2003, Banu et al. 2008b). Briefly, tissues were homogenized in TED buffer (50 mM Tris, $\mathrm{pH}$ 8.0, $10 \mathrm{mM}$ EDTA, $1 \mathrm{mM}$ diethyldithiocarbamic acid-DEDTC, and $0.1 \%$ Tween-20) and centrifuged at $30000 \mathrm{~g}$ for $1 \mathrm{~h}$ at $4{ }^{\circ} \mathrm{C}$. The homogenized tissue pellets were sonicated in TED sonication buffer (20 mM Tris, pH 8.0, $0.5 \mathrm{mM}$ EDTA, 0.1 $\mathrm{mM}$ DEDTC, $1 \mathrm{mM}$ phenylmethylsulfonyl fluoride, and protease inhibitor cocktail tablets, complete EDTA-free 1 tablet $/ 50 \mathrm{ml}$ and PhosStop 1 tablet $/ 10 \mathrm{ml}$, and $1.0 \%$ Tween-20) using a Microson ultrasonic cell disruptor (Microsonix Incorporated, Farmingdale, NY, USA) and centrifuged at $15000 \mathrm{~g}$ for $15 \mathrm{~min}$ at $4{ }^{\circ} \mathrm{C}$ and the supernatants (total protein) were stored at $-80{ }^{\circ} \mathrm{C}$ until analyzed. Total protein concentrations were determined using the Bradford method (Bradford 1976) and a Bio-Rad Protein Assay kit.

\section{Western blot}

Total protein samples $(75 \mu \mathrm{g})$ were resolved using 7.5\%, 10\%, or $12.5 \%$ SDS-PAGE and western blot was performed as we described previously (Arosh et al. 2003, Banu et al. 2008b). The blots were incubated with primary antibody for overnight at $4{ }^{\circ} \mathrm{C}$ (Table 1). Then, the blots were washed and incubated with goat anti-rabbit or anti-mouse IgG conjugated with HRP secondary antibody for $1 \mathrm{~h}$ at room temperature. Chemiluminescent substrate was applied according to the manufacturer's instructions (Pierce Biotechnology). The blots were exposed to Blue X-Ray film and densitometry of autoradiograms was performed using an Alpha Imager (Alpha Innotech Corporation, San Leandro, CA, USA).

\section{Immunohistochemistry}

Paraffin sections $(5 \mu \mathrm{m})$ were used for immunohistochemical localization of the proteins using a Vectastain Elite $A B C$ kit (Vector Laboratories, Inc.) according to the manufacturer's protocols, and as we described previously (Arosh et al. 2003, Banu et al. 2009, 2010a). Endogenous peroxidase activity was removed by fixing sections in $0.3 \%$ hydrogen peroxide in methanol. Tissue sections were blocked in $10 \%$ goat serum for $1 \mathrm{~h}$ at room temperature, and then incubated with primary antibody for overnight at $4{ }^{\circ} \mathrm{C}$ (Table 1). The tissue sections were further incubated with the secondary antibody (goat antirabbit IgG biotinilated) for $45 \mathrm{~min}$ at room temperature. For the negative control, serum or IgG from respective species with reference to the primary antibody at the respective dilution was used.

Digital images were captured using a Zeiss Axioplan 2 Research Microscope (Carl Zeiss, Thornwood, NY, USA) with an Axiocam HR digital color camera. The intensity of staining for each protein was quantified using Image-Pro Plus 6.3 image processing and analysis software according to the manufacturer's instructions (Media Cybernetics, Inc., Bethesda, MD, USA). The detailed methods for quantification are given in the instruction guide: 'The Image-Pro Plus (Media Cybernetics, Inc.): the proven solution for image analysis'. In brief: a minimum of three images of at $\times 400$ magnification were captured randomly without hot-spot bias in each tissue section per animal. Integrated optical intensity (IOD) of immunostaining was quantified under RGB mode as we published recently (Lee et al. 2012). Numerical data were expressed as least square mean \pm S.E.M. This technique is more quantitative than conventional blind scoring systems and the validity of the quantification was reported previously by our group (Arosh et al. 2003, Banu et al. 2010b, Lee et al. 2012).

\section{Progesterone assay}

Jugular venous blood samples were collected in tubes treated with EDTA $10.8 \mathrm{mg}$ at the time of necropsy and plasma was separated immediately. Concentrations of progesterone in plasma were determined using DSL-3900 ACTIVE Progesterone Coated-Tube RIA kit according to the manufacturer's instructions (Diagnostic Systems Laboratories). The RIA used rabbit anti-progesterone immunoglobulin-coated tubes and iodinated progesterone. The primary antiserum cross-reacts $6.0,2.5,1.2,0.8,0.48$, and $0.1 \%$ with $5 \alpha$-pregnane-3,20dione, 11-deoxycorticosterone, 17 $\alpha$-hydroxyprogesterone, $5 \beta$-pregnane-3,20-dione, 11-deoxycortisol, and 20 $\beta$-dihydroprogesterone respectively. The progesterone standard curve $(0-10.57 \mathrm{ng} / \mathrm{ml})$ was provided in the assay kit. The sensitivity or minimum detection limit of this assay is $\sim 0.12 \mathrm{ng} / \mathrm{ml}$. The intra-assay variation was $8.8 \%$.

\section{Statistical analyses}

Statistical analyses were performed using general linear models of Statistical Analysis System (SAS, Cary, NC, USA). Data were checked for normality or homogeneity of variance before analyzing the data statistically. Day $(12,14$, or 16) and status (estrous cycle vs pregnancy) interactions on expression of various proteins were tested using repeated measures for multivariate analysis of variance. Comparison of means was tested by Wilks' Lambda or Orthogonal contrast tests. Effects of day 16 of the estrous cycle or pregnancy on cell-specific expression of various proteins in luteal cells were analyzed using one-way ANOVA. Comparison of means was performed by Tukey HSD test. Numerical data are presented as least squares means with standard errors. Statistical significance was considered as $P<0.05$. The statistical model accounted for sources of variation including treatments, replicates, and ewes as appropriate.

\section{Results \\ Functional and structural luteolysis}

We determined the concentration of $\mathrm{P}_{4}$ in plasma and luteal tissue weight/volume (Fig. 1). The plasma 

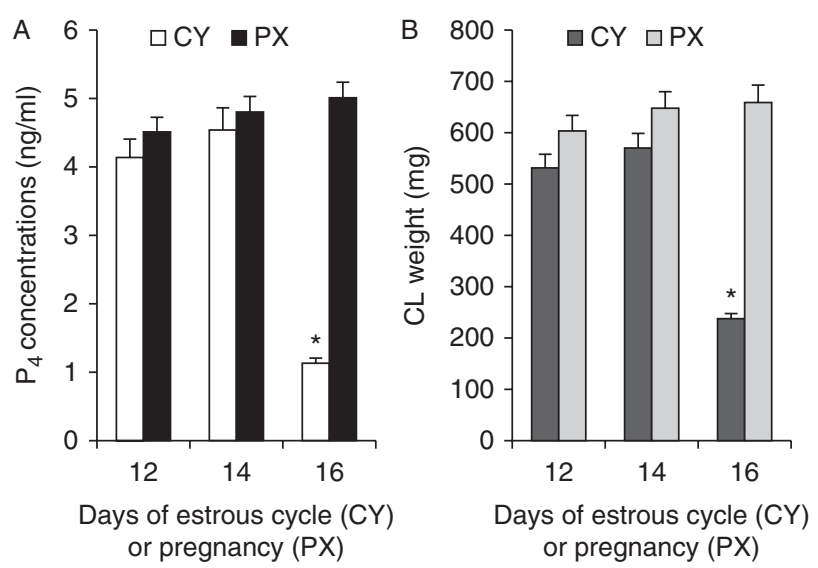

Figure 1 Progesterone concentration and luteal weight/volume. (A) $\mathrm{P}_{4}$ concentration. (B) Luteal weight/volume. Jugular venous blood samples were collected on days 12,14 , and 16 of the $\mathrm{CY}$ or PX. The $\mathrm{CL}$ was collected on days 12,14 , and 16 at necropsy. ${ }^{*} \mathrm{CY}$ vs $\mathrm{PX}, P<0.05$. The numerical data were expressed in least square S.E.M., $n=4$ for each day. More details are given in the Materials and methods section.

concentration of $\mathrm{P}_{4}$ was $\sim 4.1 \mathrm{ng} / \mathrm{ml}$ on day 12 and decreased $(P<0.05)$ to $\sim 1.1 \mathrm{ng} / \mathrm{ml}$ on day 16 of the estrous cycle $(C Y)$ whereas the $\mathrm{P}_{4}$ concentration was maintained $(P<0.05)$ at $4.3-4.9 \mathrm{ng} / \mathrm{ml}$ between days 12 and 16 of pregnancy (PX). The mean weight of the $\mathrm{CL}$ decreased from day $14(\sim 600-625 \mathrm{mg})$ to 16 of the $\mathrm{CY}$ ( $200-225 \mathrm{mg})$. In contrast, it was maintained at $600-700 \mathrm{mg}(P<0.05)$ on days 12,14 , and 16 of PX. These results together indicted that the $\mathrm{CL}$ entered into functional as well as structural luteolytic processes on day 16 of the $C Y$; by contrast, the $C L$ was rescued from both functional and structural luteolysis at the time of establishment of pregnancy.

\section{Regulation of cell survival signaling protein machinery in the $C L$ at luteolysis and establishment of pregnancy}

We determined temporal regulation of important cell survival signaling proteins in the $\mathrm{CL}$ on days 12,14 , and 16 of the CY and PX (Fig. 2).

Expression of $p$-EGFR protein was unchanged on days $12-16$ of the CY and PX. Expression of $\mathrm{p}$-ERK1/2 protein was decreased $(P<0.05)$ on days 14-16 compared with day 12 of the CY. In contrast, it was abundantly expressed without significant modulation on days 12-16 of PX. CY-PX interaction indicated that expression of p-ERK $1 / 2$ protein was sustained $(P<0.05)$ on days $14-16$ of PX compared with that of the $C Y$.

Expression of p-AKT473 protein was decreased $(P<0.05)$ on day 16 compared with days $12-14$ of the CY. In contrast, it was abundantly expressed without significant modulation on days 12-16 of PX. CY-PX interaction indicated that expression of $\mathrm{p}$-AKT473 protein was sustained $(P<0.05)$ on day 16 of $\mathrm{PX}$ compared with that of the CY.

$\beta$-catenin protein was constantly expressed at low level on days 12-16 of the CY. In contrast, it was constantly expressed at high level on days 12-16 in PX. CY-PX interaction indicated that expression of $\beta$-catenin protein was increased $(P<0.05)$ on days $12-16$ of PX compared with that of the $\mathrm{CY}$.

$p$-GSK3 $\beta$ protein was expressed at very low levels on days $12-16$ of the CY. In contrast, it was abundantly expressed on days 12-14 of PX. Notably, its expression was decreased $(P<0.05)$ on day 16 compared with days 12-14 of PX. CY-PX interaction indicated that expression p-GSK3 $\beta$ protein was increased $(P<0.05)$ on days $12-16$ of PX compared with that of the CY.

Expression of NFкB-p50 protein was very low on days 12-16 of the CY. In contrast, it was abundantly expressed on days 12-14 of PX. Notably, its expression was decreased $(P<0.05)$ on day 16 compared with days 12-14 of PX. CY-PX interaction indicated that expression NFKB-p50 protein was increased $(P<0.05)$ on days $12-16$ of $P X$ compared with that of the $C Y$.

Expression of NFKB-p52 protein was temporally decreased $(P<0.05)$ on days 14-16 compared with day 12 of the CY. In contrast, it was abundantly expressed without significant modulation on days 12-16 of PX. CY-PX interaction indicated that expression of NFKB-p52 protein was sustained $(P<0.05)$ on days 14-16 of PX compared with that of the $\mathrm{CY}$.

Expression of NFKB-p65 protein was decreased $(P<0.05)$ on days $14-16$ compared with day 12 of the CY. In contrast, it was abundantly expressed without significant modulation on days $12-16$ of PX. CY-PX interaction indicated that expression of NFкB-p65 protein was increased $(P<0.05)$ on days $14-16$ of $\mathrm{PX}$ compared with that of the CY.

Expression of Ras protein was decreased $(P<0.05)$ on day 16 compared with days $12-14$ of the CY. In contrast, it was abundantly expressed without modulation on days 12-16 of PX. CY-PX interaction indicated that expression of Ras protein was sustained $(P<0.05)$ on days 16 of the PX compared with that of the CY.

Expression of $\mathrm{p}$-cRaf protein was decreased $(P<0.05)$ temporally on days $14-16$ compared with day 12 of the CY. In contrast, it was abundantly expressed without significant modulation on days $12-16$ of PX. CY-PX interaction indicated that expression of $\mathrm{p}$-cRaf protein was increased $(P<0.05)$ on days $14-16$ of PX compared with that of the $\mathrm{CY}$.

Expression of $p$-Src416 protein was temporally decreased $(P<0.05)$ on days $14-16$ compared with day 12 of the $C Y$. In contrast, it was highly expressed without modulation on days 12-16 of PX. CY-PX interaction indicated that expression of $\mathrm{p}$-Src416 protein was increased $(P<0.05)$ on days $14-16$ of PX compared with that of the $C Y$. 
A

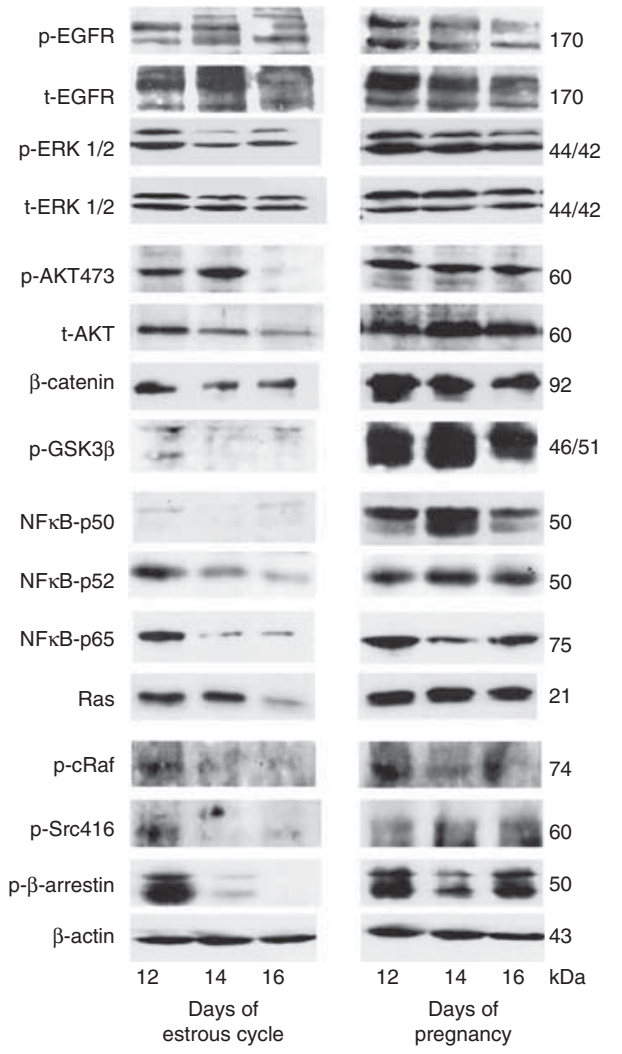

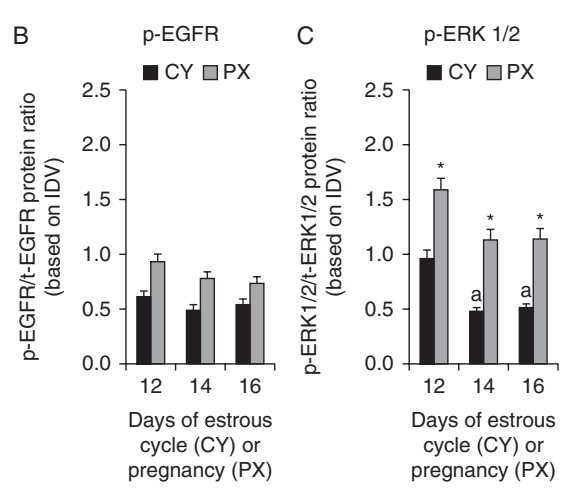

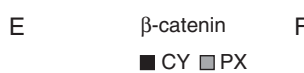

$\begin{array}{cl}\mathrm{p} & \mathrm{p}-\mathrm{GSK} 3 \beta \\ \mathbf{C Y} \square \mathrm{PX}\end{array}$
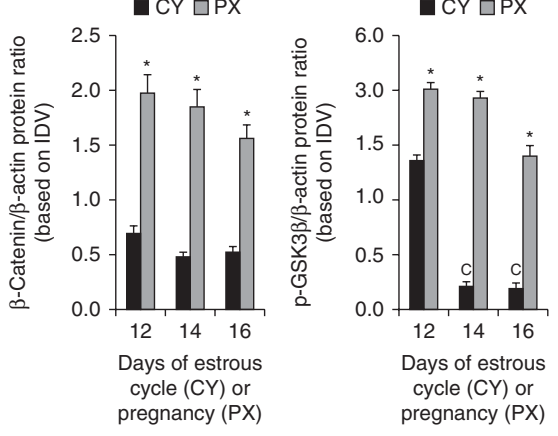

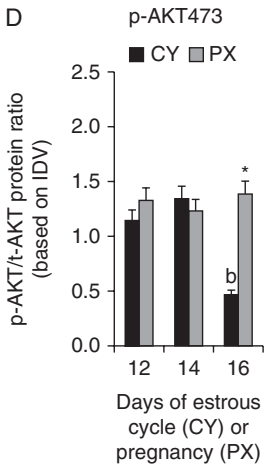

G NFkB-p50
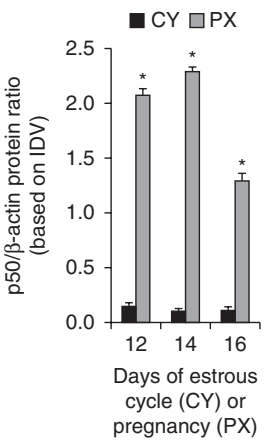
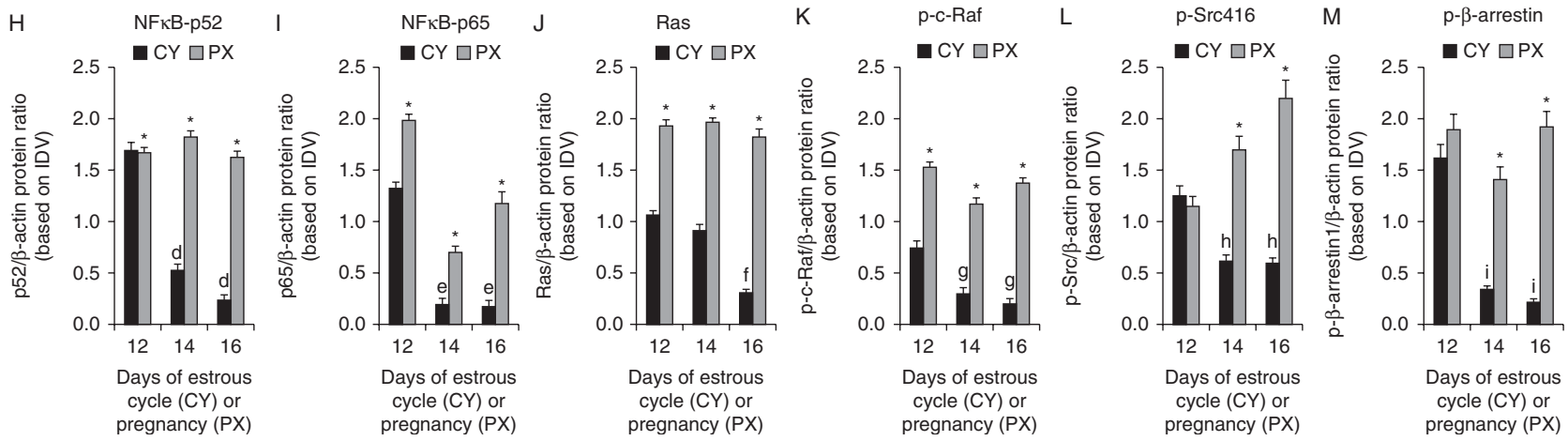

Figure 2 Temporal expression of cell survival signaling proteins in the CL on days 12, 14, and 16 of the CYand early PX in sheep. (A) Western blot analysis. $\beta$-actin protein was measured as an internal control. (B, C, D, E, F, G, H, I, J, K, L and M) Densitometry. *Denotes comparisons of expression pattern of respective protein on days 12,14 , or 16 of the $C Y$ vs $P X, P<0.05$. Letters ' $\mathrm{a}-\mathrm{i}$ ' denote changes in expression pattern of respective protein on days 12,14 , or

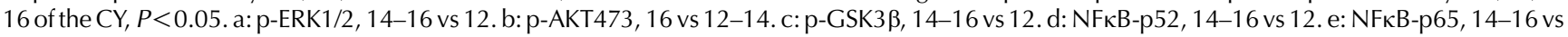
12.f: c-Ras, 16 vs 12-14. g: p-c-Raf, 16 vs 12-14. h: p-Src416, 14-16 vs 12. i: p- $\beta$-arrestin, 14-16 vs 12 . Densitometry was performed using Alpha Imager and expressed at integrated density value (IDV). The numerical data are expressed in least square s.E.M., $n=4$ for each day.

Expression of $\beta$-arrestin protein was temporally decreased $(P<0.05)$ on days $14-16$ compared with day 12 of the $\mathrm{CY}$. $\beta$-arrestin protein was abundantly expressed without significant modulation on days 12-16 of PX. CY-PX interaction indicated that expression of $\beta$-arrestin protein was sustained $(P<0.05)$ on days 14-16 of PX compared with that of the CY.

Spatial expressions of p-ERK1/2, p-AKT473, $\beta$-catenin,

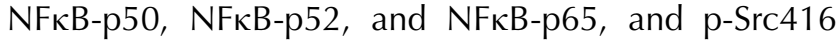
proteins in LLC and SLC were increased $(P<0.05)$ on day 16 of PX compared with that of CY (Fig. 3).

\section{Regulation of intrinsic apoptotic pathway proteins in the $C L$ at luteolysis and establishment of pregnancy}

We determined temporal regulation of important intrinsic apoptotic pathway proteins in the $\mathrm{CL}$ on days 12, 14, and 16 of the CY and PX (Fig. 4).

$\mathrm{Bcl}-\mathrm{XL}$ protein was expressed at very low level on days 12-16 of the CY. In contrast, it was abundantly expressed without significant modulation on days 12-16 of PX. $\mathrm{CY}-\mathrm{PX}$ interaction indicated that $\mathrm{BCl}-\mathrm{XL}$ protein was increased $(P<0.05)$ on days $12-16$ of PX compared with that of the $\mathrm{CY}$. 


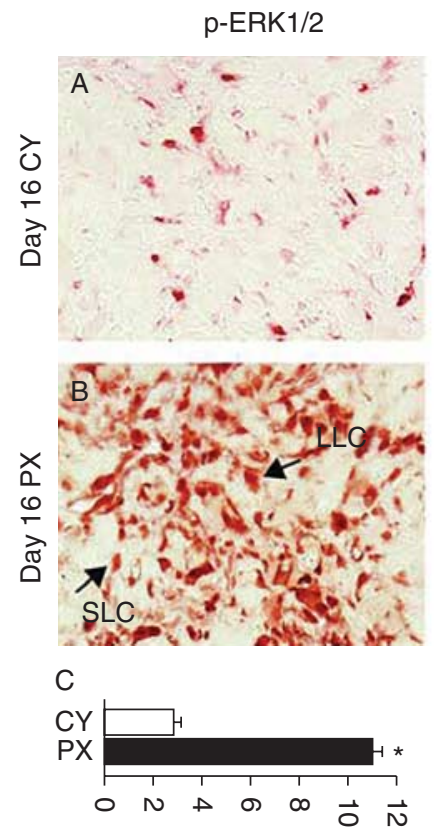

Relative expression (based on IOD, $1 \times 10^{3}$ )
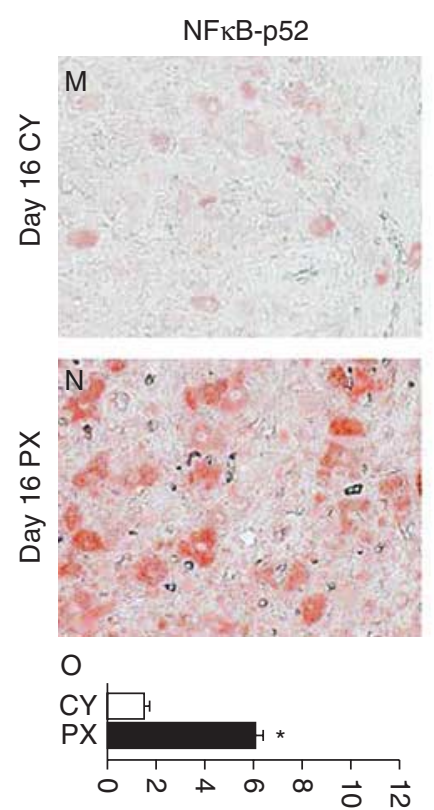

Relative expression (based on IOD, $1 \times 10^{3}$ )
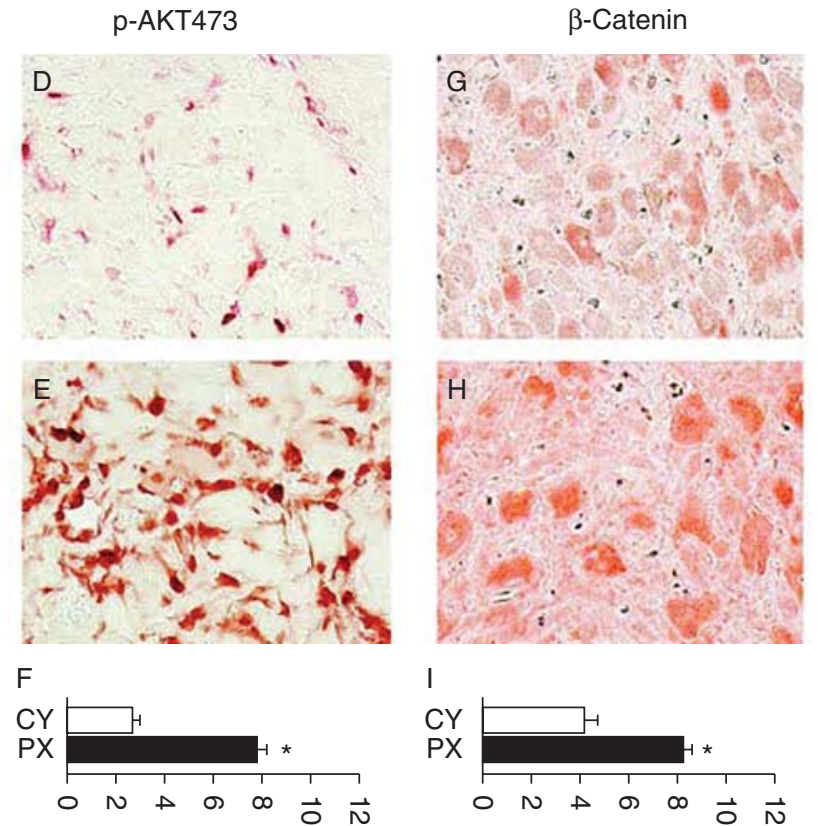

Relative expression (based on IOD, $1 \times 10^{3}$ )

NFкB-p65
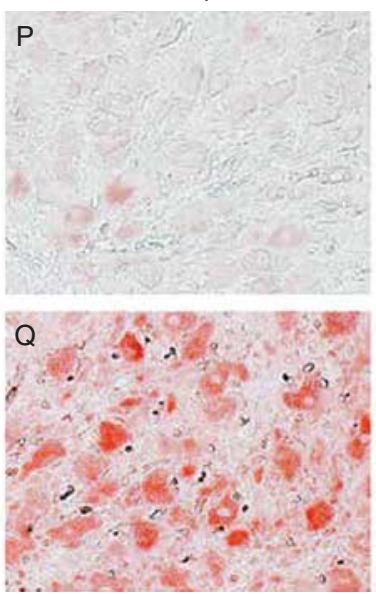

$\mathrm{R}$

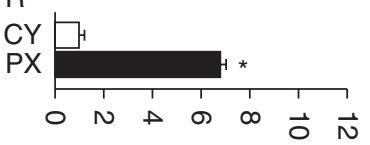

Relative expression (based on IOD, $1 \times 10^{3}$ )

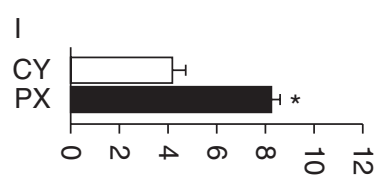

Relative expression (based on IOD, $1 \times 10^{3}$ )

p-Src416
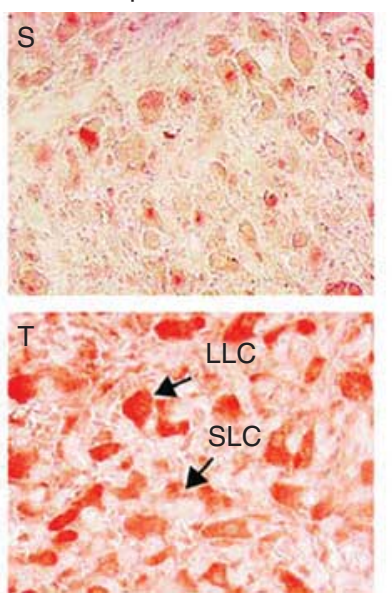

$\mathrm{U}$

CY
PX

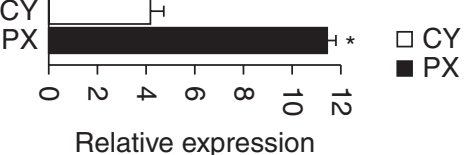

L

W
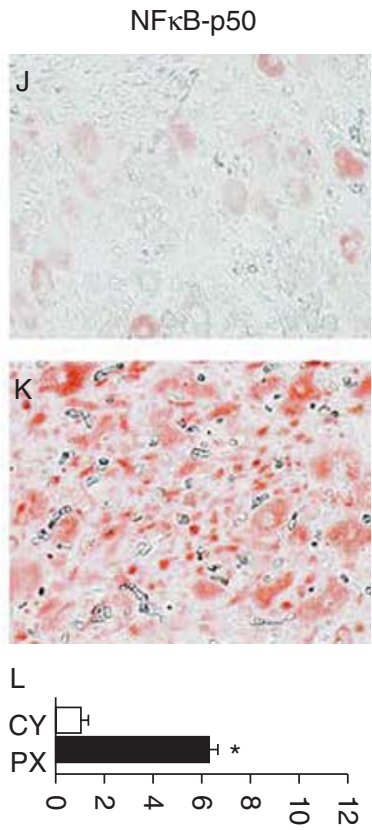

Relative expression (based on IOD, $1 \times 10^{3}$ )

$\lg G$
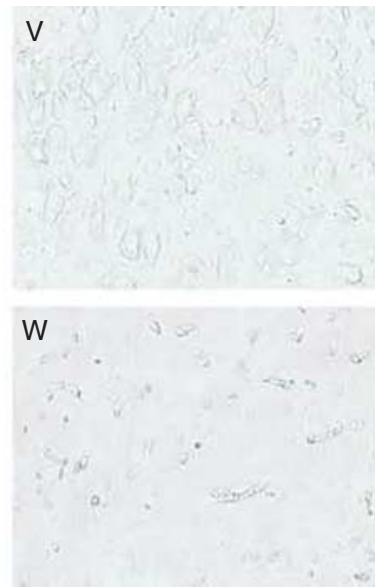

Figure 3 Cellular localization of cell survival signaling proteins in the $C L$ on day 16 of the CY and early PX in sheep. (A, B and C) p-ERK1/2, (D, E and F)

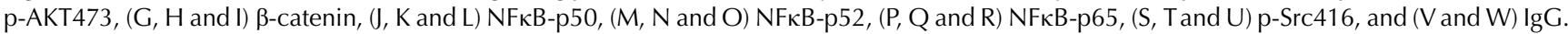
LLC, large luteal cells; SLC, small luteal cells. (C, F, I, L, O, R and U) Relative expression: *Expression of each protein on day 16 of the CY vs PX, $P<0.05$. Immunohistochemistry was performed using Vectastain Elite ABC kit (Vector Laboratories, Inc.) and representative photomicrographs at $400 \times$ magnification are shown. Densitometry of relative spatial expression of each protein in both LLC and SLC was quantified using Image-Pro Plus (Media Cybernetics, Inc.) and expressed as IOD. The numerical data are expressed in least square s.E.M. Statistical significance was $P<0.05$.

Please see text in Materials and methods for more details.

Bcl-2 protein was expressed at a very low level on day 12 and further decreased $(P<0.05)$ on days $14-16$ of the CY. In contrast, it was abundantly expressed without significant modulation on days $12-16$ of PX. CY-PX interaction indicated that $\mathrm{Bcl}-2$ protein was increased $(P<0.05)$ on days $12-16$ of PX compared with that of the CY.

Expression of Bad protein was not significantly modulated on days $12-16$ of the CY. Bad protein was 
A

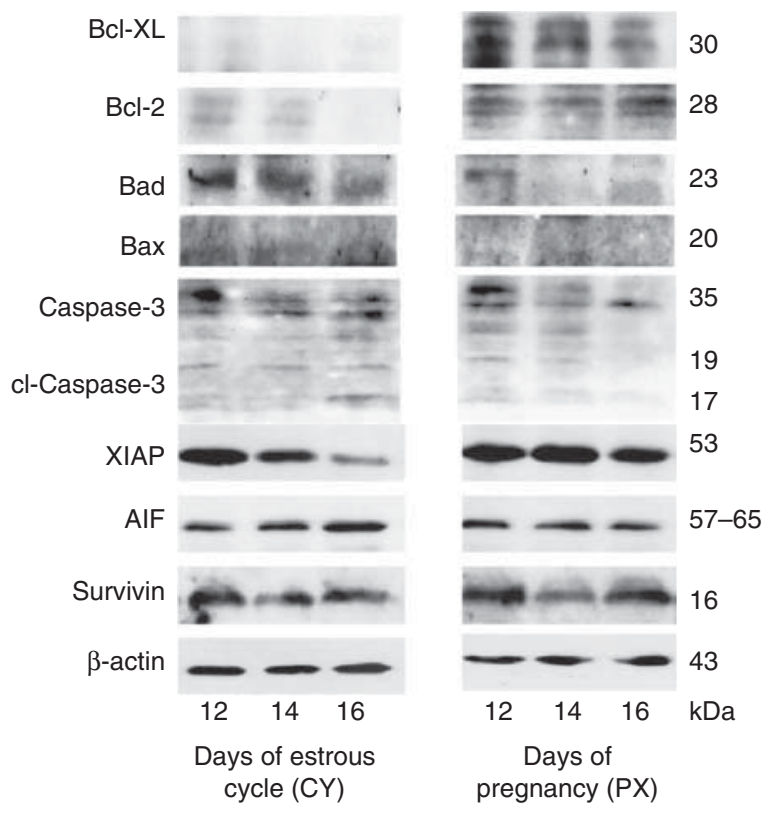

B

$\mathrm{Bcl}-\mathrm{XL}$

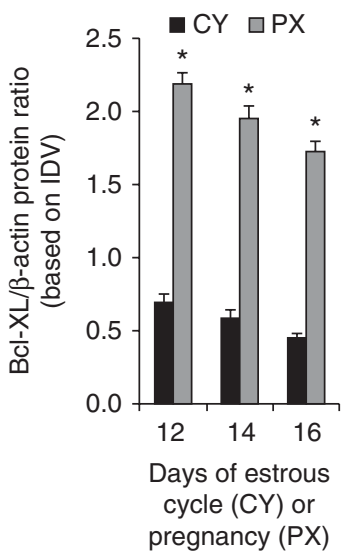

$\mathrm{F}$

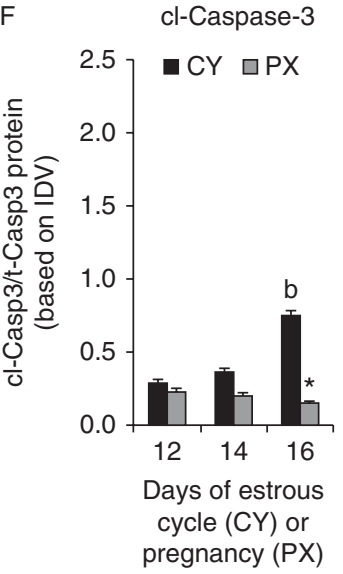

C

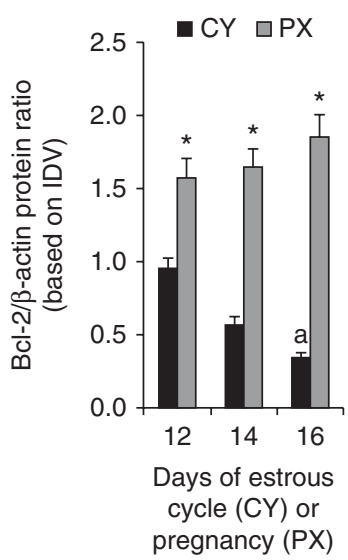

G

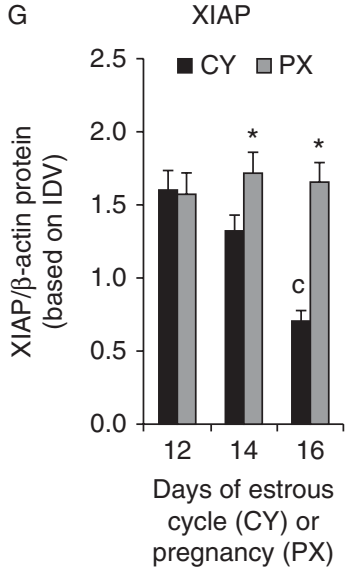

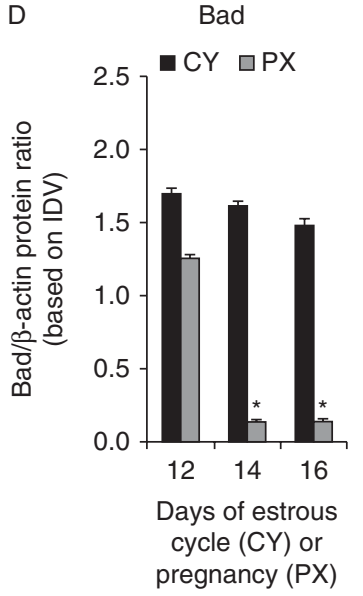

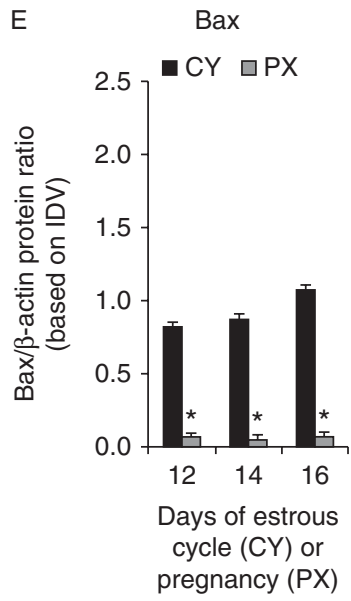

$\mathrm{H}$

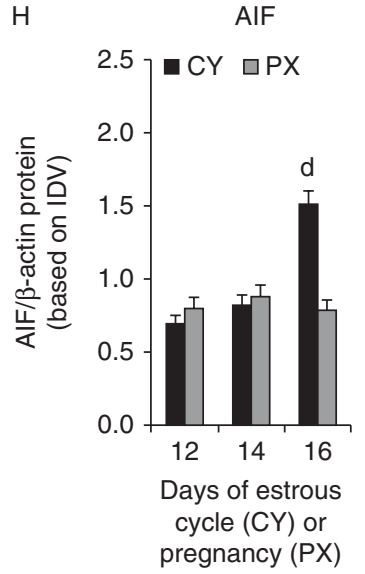

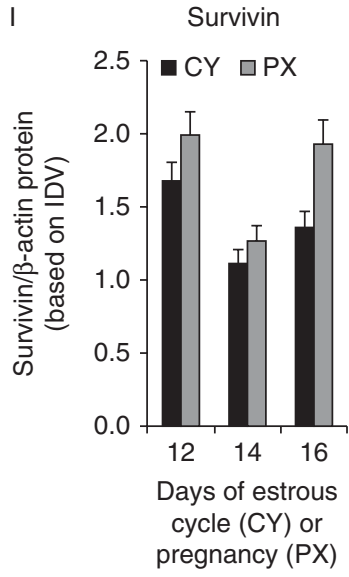

Figure 4 Temporal expression of intrinsic apoptosis signaling proteins in the CL on days 12, 14 and 16 of the CY and early PX in sheep. (A) Western blot analysis. $\beta$-actin protein was measured as an internal control. (B, C, D, E, F, G, H and I) Densitometry. *Denotes comparisons of expression pattern of respective protein on days 12,14 , or 16 of the $C Y$ vs $P X, P<0.05$. Letters ' $a-d$ ' denote changes in expression pattern of respective protein on days 12,14 , or 16 of the $C Y, P<0.05$. a: Bcl2, 16 vs 12-14. b: cl-caspase-3, 16 vs 12-14. C: XIAP, 16 vs $14-12$. d: AIF, 16 vs $14-12$. Densitometry was performed using Alpha Imager and expressed at IDV. The numerical data are expressed in least square S.E.M., $n=4$ for each day. 
expressed on day 12 and its expression was decreased $(P<0.05)$ on days $14-16$ of PX. CY-PX interaction indicated that Bad protein was decreased $(P<0.05)$ on days 14-16 of PX compared with that of the CY.

Bax protein was minimally expressed at constant level on days 12-16 of the CY; while, it was expressed at very low level or not detectable on days $12-16$ of PX. CY-PX interaction indicated that Bax protein was $(P<0.05)$ decreased on days $12-16$ of PX compared with that of the $\mathrm{CY}$.

Caspase-3 protein was detected at 35, 19, and $17 \mathrm{kDa}$. The cleaved protein detected at $17 \mathrm{kDa}$ was an active form. Caspase-3 protein was cleaved at $17 \mathrm{kDa}$ $(P<0.05)$ on day 16 compared with that of days $12-14$ of the CY. In contrast, caspase-3 protein was not cleaved at $17 \mathrm{kDa}$ on days $12-16$ of PX. CY-PX interaction indicated that caspase- 3 protein was not cleaved at $17 \mathrm{kDa}(P<0.05)$ on day 16 of PX compared with that of the $C Y$.

Expression of $X$-linked inhibitor of apoptosis protein (XIAP) protein was temporally decreased $(P<0.05)$ from days $12-16$ and suppressed on day 16 of the CY. In contrast, it was $(P<0.05)$ expressed at steady state levels on days $12-16$ of PX. CY-PX interaction indicated that XIAP protein was highly expressed on days $14-16$ of PX compared with that of the CY.

Expression of apoptosis inducing factor (AIF) protein was increased $(P<0.05)$ on day 16 compared with 12-14 of the CY. In contrast, it was not regulated on days 14-16 of PX. CY-PX interaction indicated that AIF protein was decreased on day 16 of PX compared with that of the CY. Expression of survivin protein was not modulated in the $\mathrm{CL}$ on days $12-16$ of the $\mathrm{CY}$ or PX.

Spatial expression of $\mathrm{BCl} 2, \mathrm{BCl}-\mathrm{XL}$, and XIAP proteins were increased $(P<0.05)$ and expression of $\mathrm{cl}$-capspe-3 and AIF proteins were decreased $(P<0.05)$ in LLC and SLC on day 16 of PX compared with that of the CY (Fig. 5).

\section{Regulation of important transcriptional factor proteins in the $C L$ at luteolysis and establishment of pregnancy}

We determined temporal regulation of important transcription factor proteins involved in cell survival and apoptosis pathways in the CL on days 12, 14, and 16 of the CY and PX (Fig. 6).

C-Fos protein was $(P<0.05)$ expressed on days $14-16$ compared with day 12 of the CY. Expression of c-Fos protein was decreased $(P<0.05)$ on days $14-16$ compared with day 12 of PX. CY-PX interaction indicated that expression of c-Fos protein was decreased on days 14-16 of PX compared with that of the CY.

Expression of c-Jun protein was temporally increased $(P<0.05)$ on days $12-16$ and highly expressed on day 16 of the CY. C-Jun protein was constantly expressed on day 12-16 of PX. CY-PX interaction indicated that expression of c-Jun protein was decreased on days 14-16 of PX compared with that of the CY.

Expression of EGR-1 protein was increased $(P<0.05)$ on day 16 compared with that of 12-14 of the CY; while, it was barely detectable on days $12-16$ of PX. CY-PX interaction indicated that EGR-1 protein was highly expressed on day 16 of PX compared with that of the CY.

Expression of $p$-CREB protein was temporally decreased $(P<0.05)$ from days $12-16$ and highly suppressed on day 16 of the CY. By contrast, p-CREB protein was temporally increased $(P<0.05)$ from days 12-16 and highly induced on day 16 of PX. CY-PX interaction indicated that $\mathrm{p}$-CREB protein was highly expressed on day 14-16 of PX compared with that of the $\mathrm{CY}$.

Spatial expression of c-Jun and EGR-1 proteins were decreased $(P<0.05)$ and expression of $p$-CREB protein was increased $(P<0.05)$ in LLC and SLC on day 16 of PX compared with that of the $\mathrm{CY}$ (Fig. 7).

\section{Discussion}

The $C L$ is a transient endocrine gland. Functional and structural demise of the $C L$ allows a new estrous cycle. On the other hand, maintenance of the $C L$ and its secretion of $\mathrm{P}_{4}$ are required for establishment of pregnancy. Secretion of $\mathrm{P}_{4}$ depends on the survival of luteal cells which is precisely controlled by interactions between cell survival and apoptosis pathways (McCracken et al. 1999).

In the mammalian cells, ERK1/2, AKT, NFKB, and $\beta$-catenin signaling are well characterized as prosurvival pathways. It is well known that activation of EGFR in turn triggers Ras-Raf-ERK1/2 and PI3K-AKT signaling modules (Zandi et al. 2007). Heterodimer complex of p50/p65 or p52/p65 is the most common active form of NFKB signaling in the majority of cells. In the absence of $\mathrm{NF \kappa B}$ stimuli, p50, p52, and p65 proteins are sequestered in the cytoplasm with their inhibitory protein $1 \kappa B \alpha$ and form $\mathrm{p} 50 / \mathrm{p} 65 / \mathrm{l} \kappa \mathrm{B}$ or $\mathrm{p} 52 / \mathrm{p} 65 / \mathrm{l} \kappa \mathrm{B}$ inactive protein complex. In response to cytokines TNF $\alpha$, IL $1-\beta$ or other stimuli, I $\mathrm{B} \alpha \alpha$ protein is phosphorylated and targeted for protein degradation. It allows formation of active p50/p65 or p52/p65 heterodimer and translocation of these protein complexes into the nucleus (Kumar et al. 2004). $\beta$-catenin protein is the active component of Wnt signaling. In the absence of Wnt or other Wnt-related signaling, $\beta$-catenin protein is sequestered in the cytosol by scaffold protein complex consists of glycogen synthase kinase $3 \beta$ (GSK3 $\beta$, axin, and adenomatosis polyposis coli, and targeted for protein degradation). In response to stimuli, $\beta$-catenin is released from this destruction complex and translocates into nucleus (Grigoryan et al. 2008). Importantly, recent studies indicate that GPCR signaling intracellularly transactivates: i) EGFR through a c-Src/ $\beta$-arrestin 1 complex which in turn activates ERK1/2 and PI3K-AKT 

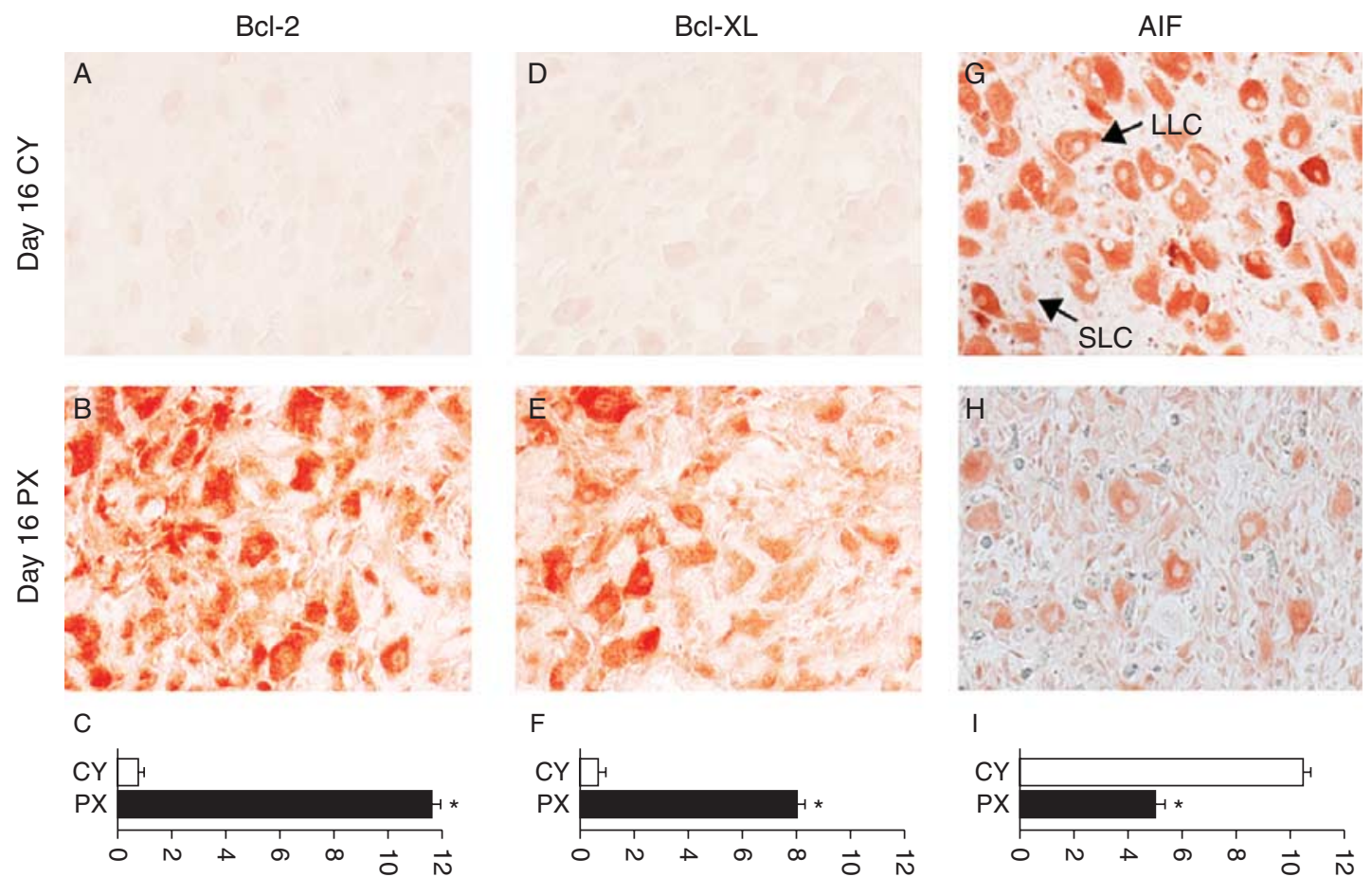

Relative expression (based on IOD, $1 \times 10^{3}$ )

$\mathrm{F}$
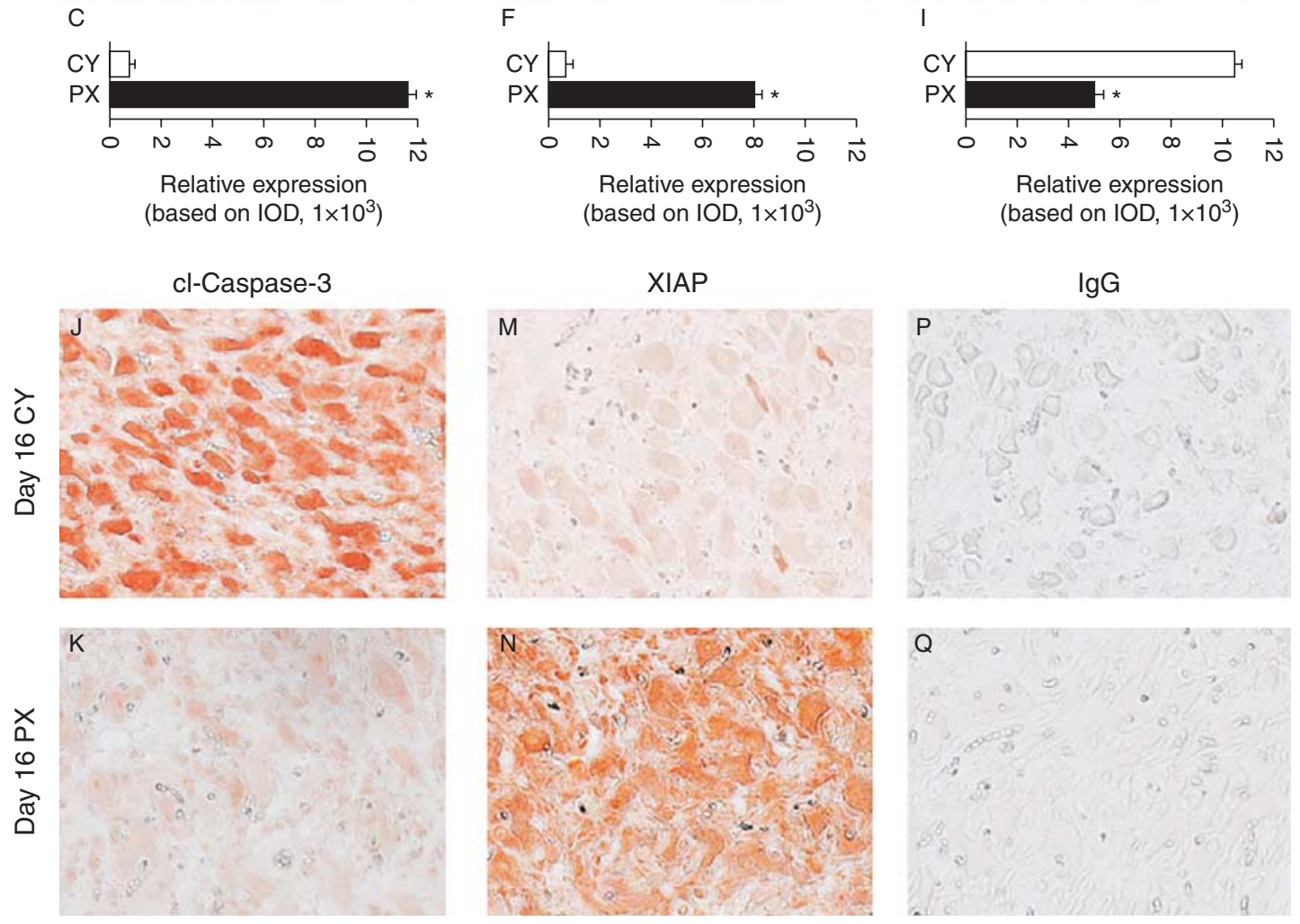

L

O

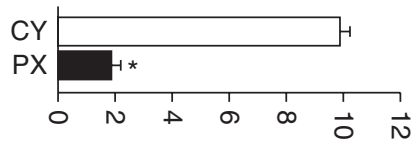

Relative expression (based on IOD, $1 \times 10^{3}$ )

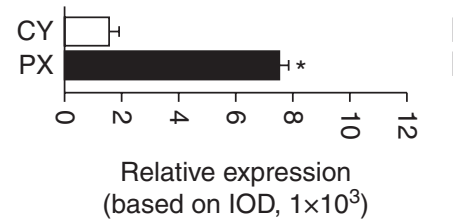
(based on IOD, $1 \times 10^{3}$ )

Figure 5 Cellular localization of cell survival signaling proteins in the $C L$ on day 16 of the $C Y$ and early $P X$ in sheep. (A, B and C) BCl-2, (D, E and F) Bcl-XL, (G, H and I) AIF, (J, K and L) Cl-caspase-3, (M, N and O) XIAP, (P and Q) IgG. LLC, large luteal cells; SLC, small luteal cells. (C, F, I, L and O) Relative expression: *Expression of each protein on day $16 \mathrm{CY}$ vs $\mathrm{PX}, P<0.05$. Immunohistochemistry was performed using Vectastain Elite ABC kit (Vector Laboratories, Inc.) and representative photomicrographs at $400 \times$ magnification are shown. Densitometry of relative spatial expression of each protein in both LLC and SLC was quantified using Image-Pro Plus (Media Cybernetics, Inc.) and expressed as IOD. The numerical data are expressed in least square S.E.M. Statistical significance was $P<0.05$. Please see text in Materials and methods for more details. 
A

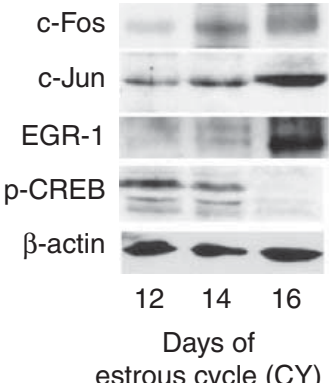

B
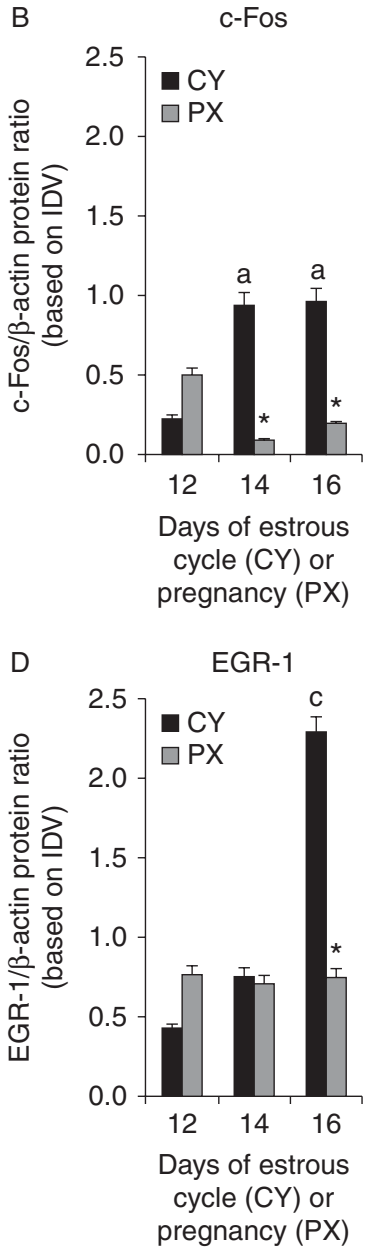
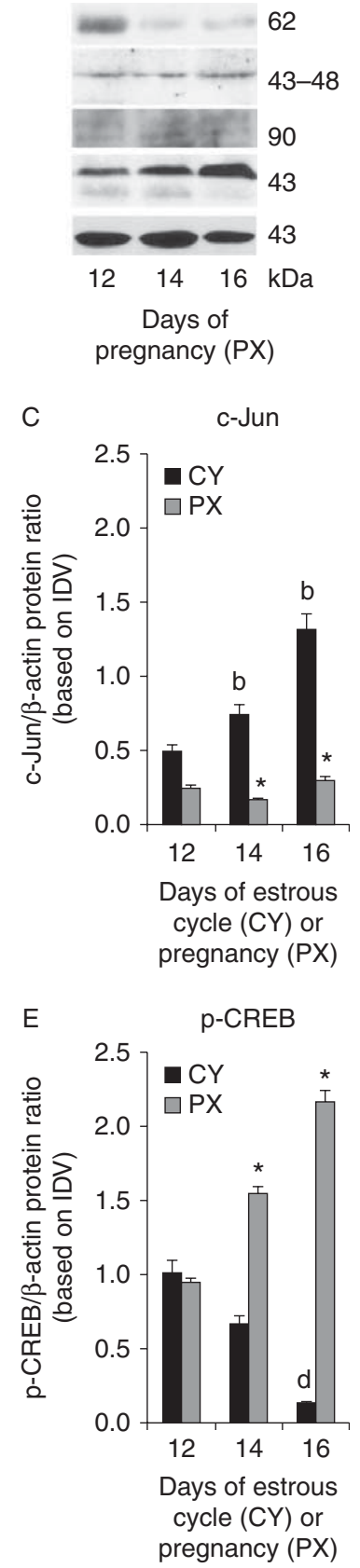

Figure 6 Temporal expression of transcriptional factors associated with cell survival and intrinsic apoptosis signaling proteins in the $\mathrm{CL}$ on days 12,14 and 16 of the CY and early PX in sheep. (A) Western blot analysis. (B, C, D and E) Densitometry. *Denotes comparisons of expression pattern of respective protein on days 12,14 , or 16 of the $C Y$ vs $P X, P<0.05$. Letters ' $a-d$ ' denote changes in expression pattern of respective protein on days 12,14 or 16 of the $C Y, P<0.05$. a: c-Fos, $14-16$ vs 12 . b: c-Jun, $14-16$ vs 12 . c: EGR-1, 16 vs $14-12$. d: $p$-CREB, 16 vs $14-12$. Densitometry was performed using Alpha Imager and expressed at IDV. The numerical data are expressed in least square S.E.M., $n=4$ for each day.

pathways (Pai et al. 2002, Regan 2003, Jabbour \& Sales 2004, Cha \& DuBois 2007); ii) $\beta$-catenin signaling pathways through axin protein and/or AKT-mediated phosphorylation/inactivation of GSK3 $\beta$ protein
(Castellone et al. 2005, Buchanan et al. 2006); and NFкB pathways (Cha \& DuBois 2007) through phosphorylation of $I \kappa B \alpha$ protein. In the present study, we determined the regulation of proteins associated with these important intracellular survival pathways in the $\mathrm{CL}$ at the time of natural luteolysis and establishment of pregnancy in sheep.

Results indicate that ERK1/2, AKT, $\beta$-catenin, NFKB, Src, $\beta$-arrestin, and GSK3 $\beta$ signaling proteins are temporally suppressed in the $C L$ from days $14-16$ of the estrous cycle. It is important to note that ERK1/2, $\beta$-catenin, NFKB, Src, and $\beta$-arrestin signaling pathways are suppressed on day 14 whereas AKT pathway is suppressed on day 16 of the estrous cycle. By contrast at time of establishment of pregnancy, expression/activation of ERK1/2, AKT, $\beta$-catenin, NFKB, Src, $\beta$-arrestin, and GSK3 $\beta$ proteins are sustained or increased on days 14-16 to maintain the function and structure of the CL. Immunohistochemistry data demonstrate that most of these proteomic changes are obvious in both LLC and SLC on day 16 of the estrous cycle or pregnancy. These results together indicate that programmed suppression of ERK1/2, AKT, $\beta$-catenin, NFKB pathways in LLC and SLC is required for natural luteolysis. In contrast, programmed activation of these pathways is required to maintain the survival of the $C L$ during establishment of pregnancy in sheep. One of the interesting findings is

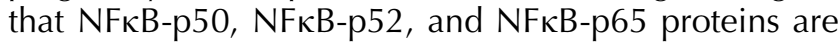
highly expressed on days 12-16 of PX compared with that of the CY. It is well known that NFKB is an important downstream mediator of inflammatory cytokines such as TNF $\alpha$, IL- $1 \beta$, and IL- 6 , and these cytokines play essential roles in induced luteolysis (Davis \& Rueda 2002). On the other hand, roles for these proinflammatory cytokines are well established in survival of tumor cells (Kumar et al. 2004). Dual role for NFKB signaling in luteolysis as well as luteal maintenance in ruminants warrants further studies.

The interactions between antiapoptotic proteins $(\mathrm{Bcl}-2$ and $\mathrm{BCl}-\mathrm{XL}$ ) and proapoptotic proteins (Bad and Bax) determine the survival or apoptosis of cells (Adams \& Cory 1998). ERK1/2, AKT, $\beta$-catenin, and NFKB pathways interact with proapoptotic and antiapoptotic proteins (Datta et al. 1997, Bonni et al. 1999, Kumar et al. 2004, Grigoryan et al. 2008). In the absence of apoptotic stimuli, Bax and Bad proteins are phosphorylated at serine 112 and 136 by ERK $1 / 2$ and AKT pathways and sequestered in the cytosol with 14-3-3 proteins (Zha et al. 1996). In response to apoptotic stimuli, Bad and Bax proteins dissociate from 14-3-3 proteins, translocate from the cytosol to the mitochondria, dimerize with $\mathrm{Bcl}-\mathrm{XL}$ and/or $\mathrm{Bcl}-2$ proteins, and thereby facilitate the release of cytochrome $C$ from the mitochondria to the cytosol (Zha et al. 1996, Adams \& Cory 1998, Jiang \& Wang 2004). Activation of caspase-3 is the important terminal event which executes apoptosis of cells (Jiang \& Wang 2004). 

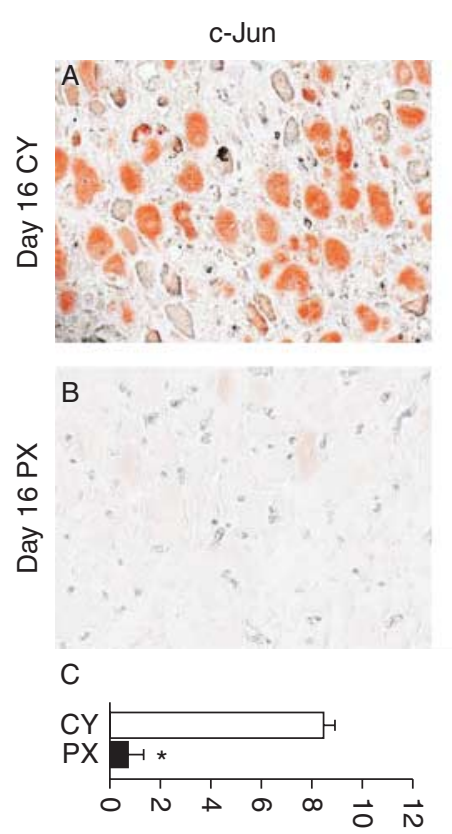

Relative expression (based on IOD, $1 \times 10^{3}$ )
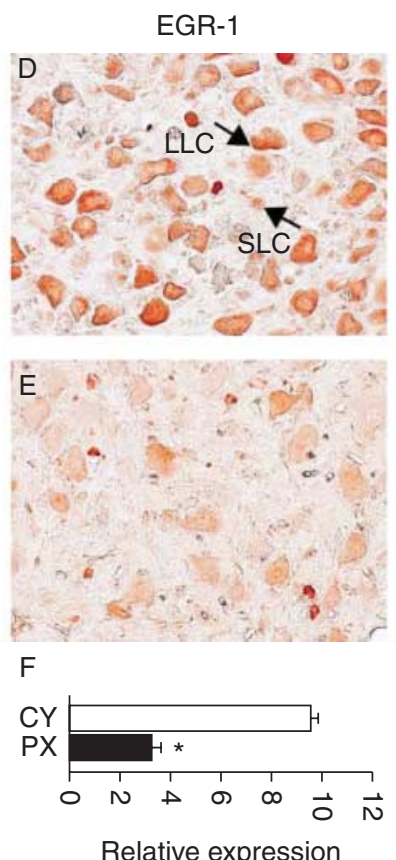

Relative expression (based on IOD, $1 \times 10^{3}$ )
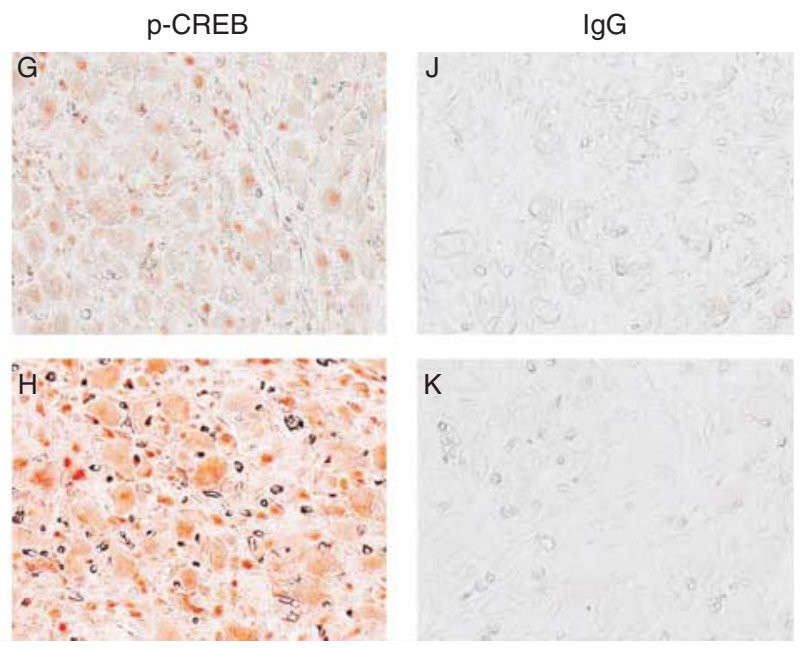

I

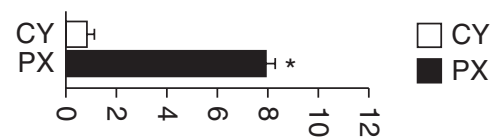

Relative expression

(based on IOD, $1 \times 10^{3}$ )

Figure 7 Cellular localization of cell survival signaling proteins in the CL on day 16 of the CY and early PX in sheep. (A, B and C) C-Jun, (D, E and F) EGR-1, (G, H and I) p-CREB, and ( and K) IgG. LLC: large luteal cells. SLC: small luteal cells. (C, F and I) Relative expression: *Expression of each protein on day $16 \mathrm{CY}$ vs $\mathrm{PX}, P<0.05$. Immunohistochemistry was performed using Vectastain Elite ABC kit (Vector Laboratories, Inc.) and representative photomicrographs at $400 \times$ magnification are shown. Densitometry of relative spatial expression of each protein in LLC and SLC was quantified using Image-Pro Plus (Media Cybernetics, Inc.) and expressed as IOD. The numerical data are expressed in least square S.E.M. Statistical significance was $P<0.05$. Please see text in Materials and methods for more details.

Activation of caspase-3 is regulated by multiple mechanisms which include cytochrome C, survivin, and XIAP pathways (Berthelet \& Dubrez 2013). In addition, apoptosis can be induced by AIF (Hangen et al. 2010) independent of caspase-3 pathway. In the present study, we determined the regulation of proteins involved in caspase-3 dependent as well as independent apoptotic pathways in the CL during natural luteolysis and establishment of pregnancy in sheep.

Results indicate that expressions of antiapoptotic proteins $\mathrm{BCl}-\mathrm{XL}$ and $\mathrm{Bcl}-2$ are increased; while, expressions of proapoptotic proteins Bad and Bax are decreased on days 14-16 pregnancy compared with that of the estrous cycle. These results suggest that expression of proapoptotic proteins need to be suppressed; whereas, expression of antiapoptotic proteins need to be sustained to rescue the $\mathrm{CL}$ from luteolysis at the time of establishment of pregnancy. Caspase- 3 protein is cleaved or activated on day 16 of the estrous cycle; in contrast, its activation is inhibited on day 16 of pregnancy. It suggests an important role for caspase- 3 in natural luteolysis in sheep. Expression of XIAP protein is decreased on day 16 of the estrous cycle; whereas, its expression is sustained on day 16 of pregnancy. It suggests that decreased expression of XIAP protein may reverse its inhibitory effect and activates caspase- 3 protein independent of cytochrome $\mathrm{C}$ pathway in luteal cells during natural luteolysis in sheep. Expression of AIF protein is temporally increased on days 14-16 of the estrous cycle; while, its expression is temporally decreased on days $14-16$ of pregnancy. It suggests that AIF may induce apoptosis of luteal cells independent of caspase-3 during natural luteolysis in sheep. Immunohistochemistry data demonstrate that most of these proteomic changes are evident in both LLC and SLC on day 16 of the estrous cycle or pregnancy. Previous studies clearly indicate a role for caspase-3 in luteal cell apoptosis in various species (Carambula et al. 2002, Davis \& Rueda 2002, Peluffo et al. 2005, Yadav et al. 2005, Slot et al. 2006). Together, present results along with previous findings suggest that activation of caspase- 3 dependent as well as independent apoptosis pathways are required for natural luteolysis; whereas, these pathways need to be inhibited or suppressed to maintain the survival of the $\mathrm{CL}$ during establishment of pregnancy in sheep.

Studies using various animal models have shown that transcription factors c-Jun (Diaz et al. 2013), EGR-1 (Hou et al. 2008) and CREB (Zeleznik \& Somers 1999, Niswender 2002, Xu et al. 2005) play roles in luteal functions. Studies using various cell lines have shown that EGR-1 can induce growth proliferation, mutagenesis, proapoptosis or tissue remodeling depends on the cell context (Liu et al. 1998). AP-1 family transcription factors (c-fos, c-Jun) regulate a wide range of 


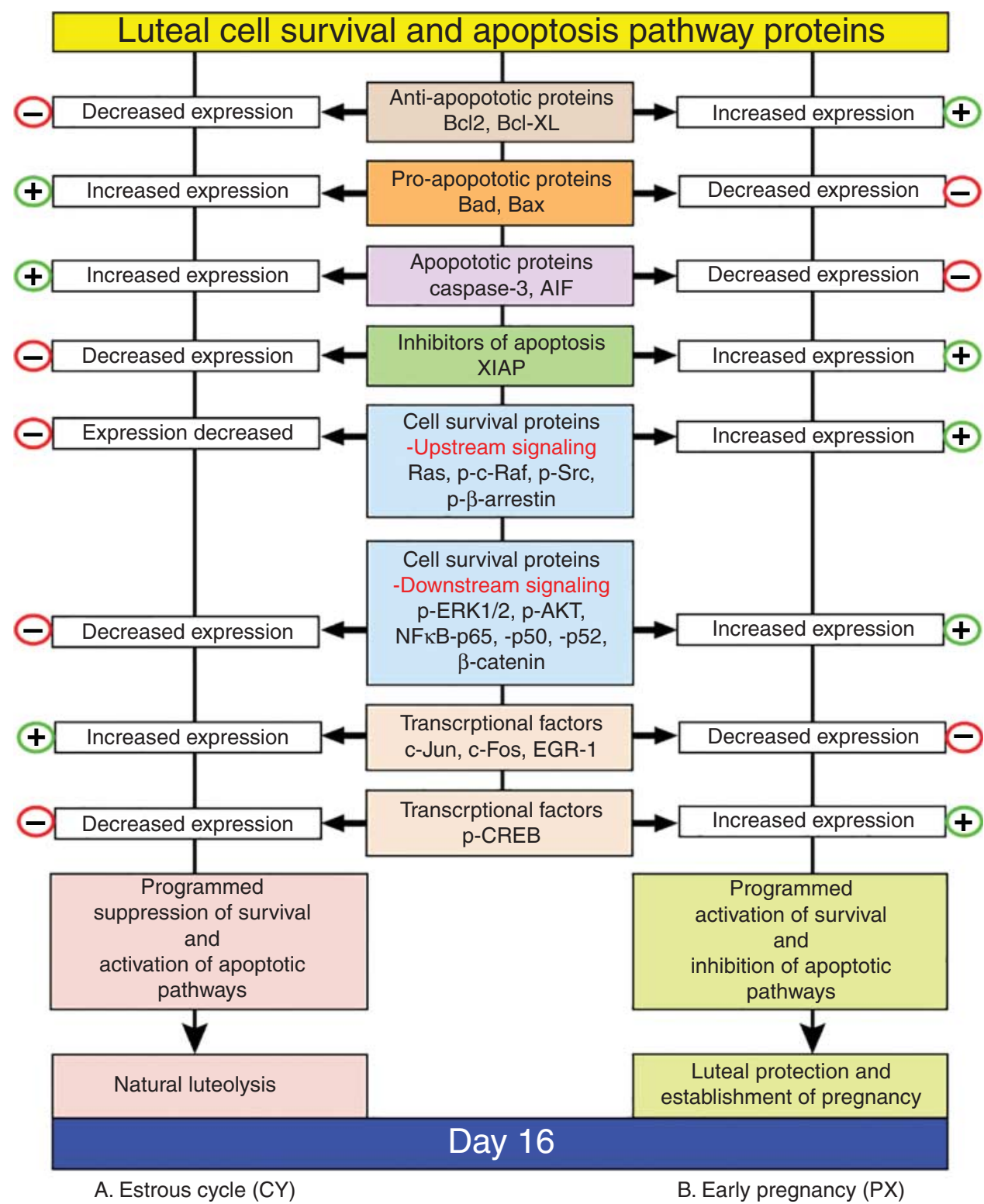

Figure 8 (A) Estrous cycle: at the time of natural luteolysis (day 16), anti-apoptotic and cell survival pathways are suppressed while pro-apoptotic and apoptotic pathways are increased. (B) Early pregnancy: in contrast at the time of establishment of pregnancy (day 16), anti-apoptotic and cell survival pathways are sustained or increased while pro-apoptotic and apoptotic pathways are inhibited. Regression of the CL during natural luteolysis vs maintenance of $\mathrm{CL}$ during establishment of pregnancy is precisely controlled by programmed intraluteal cell survival and apoptotic pathways.

More details are provided in the Results and Discussion sections.

pathophysiological responses such as cell death, inflammation, and proliferation (Shaulian \& Karin 2002). The Jun family proteins homodimerize with other Jun proteins or heterodimerize with Fos proteins and form active transcription complexes (Shaulian \& Karin 2002). The classical adenylyl cyclase/cAMP/PKA is the primary hormonal signaling module control synthesis of $\mathrm{P}_{4}$ by the CL (Zeleznik \& Somers 1999, Niswender 2002, Xu et al. 2005). CREB is one of the final transcription factors mediates CAMP-mediated signaling cascades in variety of cell types (Zeleznik \& Somers 1999, Niswender 2002, Xu et al. 2005). In the present study, given the strategic roles for AP-1, EGR-1, and CREB transcription factors in the $\mathrm{CL}$ function, we determined their regulation in the $\mathrm{CL}$ at the time of natural luteolysis and establishment of pregnancy in sheep.

Results indicate that expressions of c-Fos, c-Jun, and EGR-1 proteins are increased during luteolysis; in contrast, expressions of these proteins are suppressed during of establishment of pregnancy. Interestingly, $\mathrm{p}$-CREB protein is decreased during luteolysis; in contrast, its expression is increased during establishment of pregnancy. Immunohistochemistry data demonstrate that most of these proteomic changes are evident in both 
LLC and SLC on day 16 of the estrous cycle or pregnancy. EGR-1 and c-Fos have been shown as important key players of luteolytic acquisition in pig and cows (Chen et al. 2001, Hou et al. 2008, Atli et al. 2012, Diaz et al. 2013). $\mathrm{PGF}_{2 \alpha}-\mathrm{FP}$ interaction increases intracellular $\mathrm{Ca}^{2+}$ which activates multiple cell signaling pathways and mediates the acquisition of luteolytic sensitivity to $\mathrm{PGF}_{2 \alpha}$ in the bovine luteal cells (Goravanahally et al. 2009, Wright et al. 2014). Interactions among $\mathrm{PGF}_{2 \alpha,}$ $\mathrm{Ca}^{2+}, \mathrm{PKC}, \mathrm{ERK} 1 / 2, \mathrm{c}-\mathrm{Fos}$, and c-JUN have been shown in luteal cells in cows (Chen et al. 2001, Yadav et al. 2005). Our present results along with previous findings together indicate c-Fos, c-Jun, EGR-1, and CREB are important transcription factors which determine the apoptosis of luteal cells during natural luteolysis or survival of luteal cells during establishment of pregnancy. At present, down-stream signaling of these transcription factors is poorly understood.

The new findings of the present study is that c-Fos, c-Jun, EGR-1, CREB, caspase-3, and XIAP proteins are differentially expressed in luteal cells during natural luteolysis and establishment of pregnancy in sheep. These proteins work together as key players of acquisition of luteal cell apoptosis during natural luteolysis or acquisition of luteal cell survival during establishment of pregnancy in sheep. The other important finding is that $\beta$-catenin, NFKB-p65, Bcl-2, and $\mathrm{BCl}-\mathrm{XL}$ proteins are highly expressed on days 12-14 of PX compared with that of $\mathrm{CY}$. These results suggest that these early proteomic changes might drive the survival pathways and protect the CL from luteolysis during establishment of pregnancy. It is possible that IFNT produced by the conceptus or PGE2 produced by the conceptus and/or endometrium may activate these signaling pathways in the luteal cells as early on day 12 of pregnancy. Unraveling upstream and downstream signaling pathways associated with regulation of these proteins is expected to provide additional new molecular information on luteal function in sheep or other ruminants.

In conclusion, results of the present study together (Fig. 8) indicate that: i) during natural luteolysis, apoptosis of luteal cells may be orchestrated by suppression of multiple intracellular cell survival pathways ERK1/2, AKT, $\beta$-catenin, $\mathrm{NF \kappa B}$, and activation of intrinsic apoptosis pathways through dependent and independent mechanisms of caspase-3; ii) during establishment of pregnancy, survival of luteal cells may be precisely controlled by sustained ERK $1 / 2$, AKT, $\beta$-catenin, NFKB pathways and suppressed intrinsic apoptotic pathways; and iii) regression of the $\mathrm{CL}$ during natural luteolysis vs maintenance of $\mathrm{CL}$ during establishment of pregnancy is governed by multiple intraluteal cell signaling mechanisms in sheep. Functional studies are required to identify the factors or mediators transported from the gravid uterus to the $\mathrm{CL}$ to initiate these intraluteal signaling at the time of establishment of pregnancy in sheep/ruminants.

\section{Summary}

In sheep, multiple luteal cell survival pathways are suppressed and intrinsic apoptosis pathways are induced during natural luteolysis; whereas, these luteal cell survival pathways are sustained or increased and intrinsic apoptosis pathways are suppressed during the establishment of pregnancy.

\section{Declaration of interest}

The authors declare that there is no conflict of interest that could be perceived as prejudicing the impartiality of the research reported.

\section{Funding}

This project was supported by Agriculture and Food Research Initiative Competitive Grant nos 2008-35203-19101 and 201367015-20967 from the USDA National Institute of Food and Agriculture to J A Arosh.

\section{References}

Adams JM \& Cory S 1998 The Bcl-2 protein family: arbiters of cell survival. Science 281 1322-1326. (doi:10.1126/science.281.5381.1322)

Arosh JA, Banu SK, Chapdelaine P, Emond V, Kim JJ, MacLaren LA \& Fortier MA 2003 Molecular cloning and characterization of bovine prostaglandin E2 receptors EP2 and EP4: expression and regulation in endometrium and myometrium during the estrous cycle and early pregnancy. Endocrinology 144 3076-3091. (doi:10.1210/en.2002-0088)

Arvisais E, Hou X, Wyatt TA, Shirasuna K, Bollwein H, Miyamoto A, Hansen TR, Rueda BR \& Davis JS 2010 Prostaglandin F2 $\alpha$ represses IGF-I-stimulated IRS1/phosphatidylinositol-3-kinase/AKT signaling in the corpus luteum: role of ERK and P70 ribosomal S6 kinase. Molecular Endocrinology 24 632-643. (doi:10.1210/me.2009-0312)

Atli MO, Bender RW, Mehta V, Bastos MR, Luo W, Vezina CM \& Wiltbank MC 2012 Patterns of gene expression in the bovine corpus luteum following repeated intrauterine infusions of low doses of prostaglandin F2 $\alpha$. Biology of Reproduction 86 130. (doi:10.1095/ biolreprod.111.094870)

Banu SK, Lee J, Satterfield MC, Spencer TE, Bazer FW \& Arosh JA 2008a Molecular cloning and characterization of prostaglandin transporter in ovine endometrium: role of mitogen activated protein kinase pathways in release of prostaglandin F2 $\alpha$. Endocrinology 149 219-231. (doi:10.1210/ en.2007-1087)

Banu SK, Lee J, Speights VO, Starzinski-Powitz A \& Arosh JA 2008b Cyclooxygenase-2 regulates survival, migration and invasion of human endometriotic cells through multiple mechanisms. Endocrinology 149 1180-1189. (doi:10.1210/en.2007-1168)

Banu SK, Lee J, Speights VO Jr, Starzinski-Powitz A \& Arosh JA 2009 Selective inhibition of prostaglandin E2 receptors EP2 and EP4 induces apoptosis of human endometriotic cells through suppression of ERK1/2, AKT, NFkB and b-catenin pathways and activation of intrinsic apoptotic mechanisms. Molecular Endocrinology 23 1291-1305. (doi:10.1210/ me.2009-0017)

Banu SK, Lee J, Stephen SD, Nithy TK \& Arosh JA 2010a Interferon tau regulates PGF2 $\alpha$ release from the ovine endometrial epithelial cells through PGT-mediated mechanisms by activating novel JAK/EGFR/ ERK/EGR-1 pathways. Molecular Endocrinology 24 2315-2330. (doi:10.1210/me.2010-0205)

Banu SK, Lee J, Stephen SD, Nithy TK \& Arosh JA $2010 b$ Interferon tau regulates PGF $2 \alpha$ release from the ovine endometrial epithelial cells via activation of novel JAK/EGFR/ERK/EGR-1 pathways. Molecular Endocrinology 24 2315-2330. (doi:10.1210/me.2010-0205) 
Berthelet J \& Dubrez L 2013 Regulation of apoptosis by Inhibitors of Apoptosis (IAPs). Cells 2 163-187. (doi:10.3390/cells2010163)

Bonni A, Brunet A, West AE, Datta SR, Takasu MA \& Greenberg ME 1999 Cell survival promoted by the Ras-MAPK signaling pathway by transcription-dependent and -independent mechanisms. Science $\mathbf{2 8 6}$ 1358-1362. (doi:10.1126/science.286.5443.1358)

Bott RC, Ashley RL, Henkes LE, Antoniazzi AQ, Bruemmer JE, Niswender GD, Bazer FW, Spencer TE, Smirnova NP, Anthony RV et al. 2010 Uterine vein infusion of interferon tau (IFNT) extends luteal life span in ewes. Biology of Reproduction 82 725-735. (doi:10.1095/ biolreprod.109.079467)

Bradford MM 1976 A rapid and sensitive method for the quantitation of microgram quantities of protein utilizing the principle of protein-dye binding. Analytical Biochemistry 72 248-254. (doi:10.1016/00032697(76)90527-3)

Buchanan FG, Gorden DL, Matta P, Shi Q, Matrisian LM \& DuBois RN 2006 Role of $\beta$-arrestin 1 in the metastatic progression of colorectal cancer. PNAS 103 1492-1497. (doi:10.1073/pnas.0510562103)

Carambula SF, Matikainen T, Lynch MP, Flavell RA, Goncalves PB, Tilly JL \& Rueda BR 2002 Caspase-3 is a pivotal mediator of apoptosis during regression of the ovarian corpus luteum. Endocrinology 143 1495-1501. (doi:10.1210/endo.143.4.8726)

Castellone MD, Teramoto H, Williams BO, Druey KM \& Gutkind JS 2005 Prostaglandin E2 promotes colon cancer cell growth through a Gs-axin$\beta$-catenin signaling axis. Science 310 1504-1510. (doi:10.1126/science. 1116221)

Cha YI \& DuBois RN 2007 NSAIDs and cancer prevention: targets downstream of COX-2. Annual Review of Medicine 58 239-252. (doi:10.1146/annurev.med.57.121304.131253)

Chen D, Fong HW \& Davis JS 2001 Induction of c-fos and c-jun messenger ribonucleic acid expression by prostaglandin $\mathrm{F} 2 \alpha$ is mediated by a protein kinase C-dependent extracellular signal-regulated kinase mitogen-activated protein kinase pathway in bovine luteal cells. Endocrinology 142 887-895.

Datta SR, Dudek H, Tao X, Masters S, Fu H, Gotoh Y \& Greenberg ME 1997 Akt phosphorylation of BAD couples survival signals to the cell-intrinsic death machinery. Cell 91 231-241. (doi:10.1016/S0092-8674(00) 80405-5)

Davis JS \& Rueda BR 2002 The corpus luteum: an ovarian structure with maternal instincts and suicidal tendencies. Frontiers in Bioscience 7 d1949-d1978. (doi:10.2741/davis1)

Diaz FJ, Luo W \& Wiltbank MC 2013 Prostaglandin F2 $\alpha$ regulation of mRNA for activating protein 1 transcriptional factors in porcine corpora lutea $(\mathrm{CL})$ : lack of induction of JUN and JUND in CL without luteolytic capacity. Domestic Animal Endocrinology 44 98-108. (doi:10.1016/j. domaniend.2012.09.005)

Ginther OJ 1981 Local versus systemic uteroovarian relationships in farm animals. Acta Veterinaria Scandinavica. Supplementum 77 103-115.

Goravanahally MP, Salem M, Yao J, Inskeep EK \& Flores JA 2009 Differential gene expression in the bovine corpus luteum during transition from early phase to midphase and its potential role in acquisition of luteolytic sensitivity to prostaglandin F2 $\alpha$. Biology of Reproduction 80 980-988. (doi:10.1095/biolreprod.108.069518)

Grigoryan T, Wend P, Klaus A \& Birchmeier W 2008 Deciphering the function of canonical Wnt signals in development and disease: conditional loss- and gain-of-function mutations of $\beta$-catenin in mice. Genes and Development 22 2308-2341. (doi:10.1101/gad.1686208)

Hangen E, Blomgren K, Benit P, Kroemer G \& Modjtahedi N 2010 Life with or without AIF. Trends in Biochemical Sciences 35 278-287. (doi:10. 1016/j.tibs.2009.12.008)

Henderson KM, Scaramuzzi RJ \& Baird DT 1977 Simultaneous infusion of prostaglandin E2 antagonizes the luteolytic action of prostaglandin F2 $\alpha$ in vivo. Journal of Endocrinology 72 379-383. (doi:10.1677/joe.0. 0720379)

Hou X, Arvisais EW, Jiang C, Chen DB, Roy SK, Pate JL, Hansen TR, Rueda BR \& Davis JS 2008 Prostaglandin F2 $\alpha$ stimulates the expression and secretion of transforming growth factor B1 via induction of the early growth response 1 gene (EGR1) in the bovine corpus luteum. Molecular Endocrinology 22 403-414. (doi:10.1210/me.2007-0272)
Inskeep EK, Smutny WJ, Butcher RL \& Pexton JE 1975 Effects of intrafollicular injections of prostaglandins in non-pregnant and pregnant ewes. Journal of Animal Science 41 1098-1104.

Jabbour HN \& Sales KJ 2004 Prostaglandin receptor signalling and function in human endometrial pathology. Trends in Endocrinology and Metabolism 15 398-404. (doi:10.1016/S1043-2760(04)00187-0)

Jiang X \& Wang X 2004 Cytochrome C-mediated apoptosis. Annual Review of Biochemistry 73 87-106. (doi:10.1146/annurev.biochem.73.011303. 073706)

Kittok RJ \& Britt JH 1977 Corpus luteum function in ewes given estradiol during the estrous cycle or early pregnancy. Journal of Animal Science $\mathbf{4 5}$ 336-341.

Kumar A, Takada Y, Boriek AM \& Aggarwal BB 2004 Nuclear factor-кB: its role in health and disease. Journal of Molecular Medicine 82 434-448. (doi:10.1007/s00109-004-0555-y)

Lee J, McCracken JA, Banu SK, Rodriguez R, Nithy TK \& Arosh JA 2010 Transport of prostaglandin $\mathrm{F}(2 \alpha)$ pulses from the uterus to the ovary at the time of luteolysis in ruminants is regulated by prostaglandin transportermediated mechanisms. Endocrinology 151 3326-3335. (doi:10.1210/ en.2009-0948)

Lee J, McCracken JA, Stanley JA, Nithy TK, Banu SK \& Arosh JA 2012 Intraluteal prostaglandin biosynthesis and signaling are selectively directed towards PGF2 $\alpha$ during luteolysis but towards PGE2 during the establishment of pregnancy in sheep. Biology of Reproduction 8797. (doi:10.1095/biolreprod.112.100438)

Liu C, Rangnekar VM, Adamson E \& Mercola D 1998 Suppression of growth and transformation and induction of apoptosis by EGR-1. Cancer Gene Therapy 5 3-28.

Magness RR, Huie JM, Hoyer GL, Huecksteadt TP, Reynolds LP, Seperich GJ, Whysong G \& Weems CW 1981 Effect of chronic ipsilateral or contralateral intrauterine infusion of prostaglandin E2 (PGE2) on luteal function of unilaterally ovariectomized ewes. Prostaglandins and Medicine 6 389-401. (doi:10.1016/0161-4630(81)90071-9)

Mapletoft RJ \& Ginther OJ 1975 Adequacy of main uterine vein and the ovarian artery in the local venoarterial pathway for uterine-induced luteolysis in ewes. American Journal of Veterinary Research 36 957-963.

Mapletoft RJ, Del Campo MR \& Ginther OJ 1975 Unilateral luteotropic effect of uterine venous effluent of a gravid uterine horn in sheep. Proceedings of the Society for Experimental Biology and Medicine. Society for Experimental Biology and Medicine 150 129-133. (doi:10. 3181/00379727-150-38988)

Mapletoft RJ, Del Campo MR \& Ginther OJ 1976a Local venoarterial pathway for uterine-induced luteolysis in cows. Proceedings of the Society for Experimental Biology and Medicine. Society for Experimental Biology and Medicine 153 289-294. (doi:10.3181/00379727-15339530)

Mapletoft RJ, Lapin DR \& Ginther OJ $1976 b$ The ovarian artery as the final component of the local luteotropic pathway between a gravid uterine horn and ovary in ewes. Biology of Reproduction 15 414-421. (doi:10. 1095/biolreprod15.3.414)

McCracken JA, Custer EE \& Lamsa JC 1999 Luteolysis: a neuroendocrinemediated event. Physiological Reviews 79 263-323.

McCracken JA, Custer EE, Schreiber DT, Tsang PC, Keator CS \& Arosh JA 2012 A new in vivo model for luteolysis using systemic pulsatile

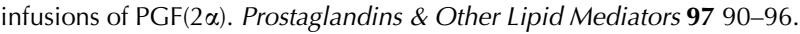
(doi:10.1016/j.prostaglandins.2012.01.004)

Moor RM \& Rowson LE 1966a The corpus luteum of the sheep: effect of the removal of embryos on luteal function. Journal of Endocrinology $\mathbf{3 4}$ 497-502. (doi:10.1677/joe.0.0340497)

Moor RM \& Rowson LE $1966 b$ Local maintenance of the corpus luteum in sheep with embryos transferred to various isolated portions of the uterus. Journal of Reproduction and Fertility 12 539-550. (doi:10.1530/jrf.0. 0120539)

Moor RM, Rowson LE, Hay MF \& Caldwell BV 1969 The corpus luteum of the sheep: effect of the conceptus on luteal function at several stages during pregnancy. Journal of Endocrinology 43 301-307. (doi:10.1677/ joe.0.0430301)

Moor RM, Hay MF, Short RV \& Rowson LE 1970 The corpus luteum of the sheep: effect of uterine removal during luteal regression. Journal of Reproduction and Fertility 21 319-326. (doi:10.1530/jrf.0.0210319) 
Nancarrow CD, Evison BM \& Connell PJ 1982 Effect of embryos on luteolysis and termination of early pregnancy in sheep with cloprostenol. Biology of Reproduction 26 263-269. (doi:10.1095/biolreprod26.2.263)

Niswender GD 2002 Molecular control of luteal secretion of progesterone. Reproduction 123 333-339. (doi:10.1530/rep.0.1230333)

Niswender GD, Davis TL, Griffith RJ, Bogan RL, Monser K, Bott RC, Bruemmer JE \& Nett TM 2007 Judge, jury and executioner: the autoregulation of luteal function. Society of Reproduction and Fertility Supplement 64 191-206.

Oliveira JF, Henkes LE, Ashley RL, Purcell SH, Smirnova NP, Veeramachaneni DN, Anthony RV \& Hansen TR 2008 Expression of interferon (IFN)-stimulated genes in extrauterine tissues during early pregnancy in sheep is the consequence of endocrine IFN-tau release from the uterine vein. Endocrinology 149 1252-1259. (doi:10.1210/en. 2007-0863)

Pai R, Soreghan B, Szabo IL, Pavelka M, Baatar D \& Tarnawski AS 2002 Prostaglandin E2 transactivates EGF receptor: a novel mechanism for promoting colon cancer growth and gastrointestinal hypertrophy. Nature Medicine 8 289-293. (doi:10.1038/nm0302-289)

Peluffo MC, Young KA \& Stouffer RL 2005 Dynamic expression of caspase-2, $-3,-8$, and -9 proteins and enzyme activity, but not messenger ribonucleic acid, in the monkey corpus luteum during the menstrual cycle. Journal of Clinical Endocrinology and Metabolism 90 2327-2335. (doi:10.1210/jc.2004-2214)

Pratt BR, Butcher RL \& Inskeep EK 1977 Antiluteolytic effect of the conceptus and of PGE2 in ewes. Journal of Animal Science 45 784-791.

Pratt BR, Butcher RL \& Inskeep EK 1979 Effect of continuous intrauterine administration of prostaglandin E2 on life span of corpora lutea of nonpregnant ewes. Journal of Animal Science 48 1441-1446.

Regan JW 2003 EP2 and EP4 prostanoid receptor signaling. Life Sciences 74 143-153. (doi:10.1016/j.Ifs.2003.09.031)

Reynolds LP, Stigler J, Hoyer GL, Magness RR, Huie JM, Huecksteadt TP, Whysong GL, Behrman HR \& Weems CW 1981 Effect of PGE1 on PGF2 $\alpha$-induced luteolysis in nonbred ewes. Prostaglandins 21 957-972. (doi:10.1016/0090-6980(81)90164-7)

Romero J, Antoniazzi AQ, Smirnova NP, Webb BT, Yu F, Davis JS \& Hansen TR 2013 Pregnancy-associated genes contribute to antiluteolytic mechanisms in ovine corpus luteum. Physiological Genomics 45 1095-1108. (doi:10.1152/physiolgenomics.00082.2013)

Shaulian E \& Karin M 2002 AP-1 as a regulator of cell life and death. Nature Cell Biology 4 E131-E136. (doi:10.1038/ncb0502-e131)

Silvia WJ \& Niswender GD 1984 Maintenance of the corpus luteum of early pregnancy in the ewe. III. Differences between pregnant and nonpregnant ewes in luteal responsiveness to prostaglandin F2 $\alpha$. Journal of Animal Science 59 746-753.

Silvia WJ \& Niswender GD 1986 Maintenance of the corpus luteum of early pregnancy in the ewe. IV. Changes in luteal sensitivity to prostaglandin F2 $\alpha$ throughout early pregnancy. Journal of Animal Science 63 1201-1207.
Simmons RM, Satterfield MC, Welsh TH Jr, Bazer FW \& Spencer TE 2010 HSD11B1, HSD11B2, PTGS2, and NR3C1 expression in the periimplantation ovine uterus: effects of pregnancy, progesterone, and interferon tau. Biology of Reproduction 82 35-43. (doi:10.1095/ biolreprod.109.079608)

Slot KA, Voorendt M, de Boer-Brouwer M, van Vugt HH \& Teerds KJ 2006 Estrous cycle dependent changes in expression and distribution of Fas, Fas ligand, Bcl-2, Bax, and pro- and active caspase-3 in the rat ovary. Journal of Endocrinology 188 179-192. (doi:10.1677/joe.1. 06165)

Spencer TE, Burghardt RC, Johnson GA \& Bazer FW 2004 Conceptus signals for establishment and maintenance of pregnancy. Animal Reproduction Science 82-83 537-550. (doi:10.1016/j.anireprosci. 2004.04.014)

Weems CW, Weems YS \& Randel RD 2006 Prostaglandins and reproduction in female farm animals. Veterinary Journal 171 206-228. (doi:10.1016/j.tvjl.2004.11.014)

Wright MF, Bowdridge E, McDermott EL, Richardson S, Scheidler J, Syed Q, Bush T, Inskeep EK \& Flores JA 2014 Mechanisms of intracellular calcium homeostasis in developing and mature bovine corpora lutea. Biology of Reproduction 90 55. (doi:10.1095/biolreprod. 113.113662)

Xu J, Stouffer RL, Searles RP \& Hennebold JD 2005 Discovery of LH-regulated genes in the primate corpus luteum. Molecular Human Reproduction 11 151-159. (doi:10.1093/molehr/gah157)

Yadav VK, Lakshmi G \& Medhamurthy R 2005 Prostaglandin F2 $\alpha$ mediated activation of apoptotic signaling cascades in the corpus luteum during apoptosis: involvement of caspase-activated DNase. Journal of Biological Chemistry 280 10357-10367. (doi:10.1074/jbc.M4095 96200)

Zandi R, Larsen AB, Andersen P, Stockhausen MT \& Poulsen HS 2007 Mechanisms for oncogenic activation of the epidermal growth factor receptor. Cellular Signalling 19 2013-2023. (doi:10.1016/j.cellsig.2007. 06.023)

Zeleznik AJ \& Somers JP 1999 Regulation of the primate corpus luteum: cellular and molecular perspectives. Trends in Endocrinology and Metabolism 10 189-193. (doi:10.1016/S1043-2760(98)00145-3)

Zha J, Harada H, Yang E, Jockel J \& Korsmeyer SJ 1996 Serine phosphorylation of death agonist BAD in response to survival factor results in binding to 14-3-3 not BCL-X(L). Cel/ 87 619-628. (doi:10.1016/ S0092-8674(00)81382-3)

Received 29 June 2015

First decision 24 August 2015

Revised manuscript received 16 November 2015

Accepted 19 November 2015 